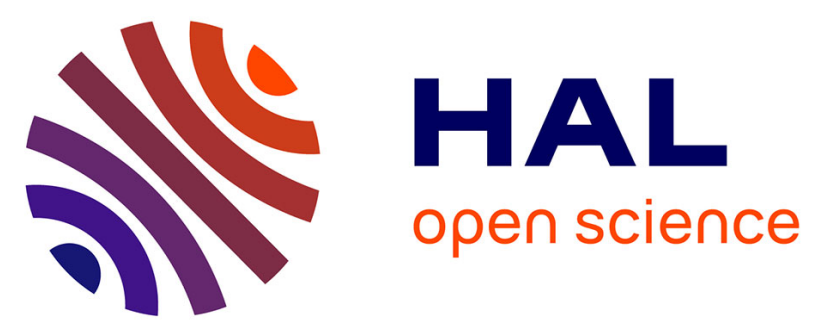

\title{
Heat storage: Hydration investigation of MgSO4/active carbon composites, from material development to domestic applications scenarios
}

Simona Bennici, Patrick Dutournie, Jérémy Cathalan, Mohamed Zbair, Minh Hoang Nguyen, Elliot Scuiller, Cyril Vaulot

\section{To cite this version:}

Simona Bennici, Patrick Dutournie, Jérémy Cathalan, Mohamed Zbair, Minh Hoang Nguyen, et al.. Heat storage: Hydration investigation of MgSO4/active carbon composites, from material development to domestic applications scenarios. Renewable and Sustainable Energy Reviews, 2022. hal-03546176

\author{
HAL Id: hal-03546176 \\ https://hal.science/hal-03546176
}

Submitted on 27 Jan 2022

HAL is a multi-disciplinary open access archive for the deposit and dissemination of scientific research documents, whether they are published or not. The documents may come from teaching and research institutions in France or abroad, or from public or private research centers.
L'archive ouverte pluridisciplinaire HAL, est destinée au dépôt et à la diffusion de documents scientifiques de niveau recherche, publiés ou non, émanant des établissements d'enseignement et de recherche français ou étrangers, des laboratoires publics ou privés. 


\title{
Heat storage: Hydration investigation of $\mathrm{MgSO}_{4}$ /active carbon composites, from material development to domestic applications scenarios
}

\author{
Nguyen $^{1,2}$, Elliot Scuiller ${ }^{1,2}$, Cyril Vaulot ${ }^{1,2}$ \\ 1 Université de Haute-alsace, CNRS, IS2M UMR 7361, F-68100 Mulhouse, France \\ 2 Université de Strasbourg, France \\ * Corresponding author details: simona.bennici@uha.fr
}

Simona Bennici ${ }^{1,2 *}$, Patrick Dutournié ${ }^{1,2}$, Jérémy Cathalan ${ }^{1,2}$, Mohamed Zbair ${ }^{1,2}$, Minh Hoang

\begin{abstract}
The scarcity of durable and low-cost sorbent materials remains a significant technological barrier to long-term heat storage. In the present work, composite materials based on activated carbon supports and magnesium sulfate hydrates (labelled $\mathrm{MgSO}_{4} / \mathrm{AC}$ ) were developed in order to increase the energy density and improve mass and heat transport phenomena. The results of composite characterization revealed uniform dispersion of magnesium sulfate in composites produced via incipient wetness impregnation. The hydration enthalpy increased as the $\mathrm{MgSO}_{4}$ content on $\mathrm{AC}$ increased, reaching a plateau for $\mathrm{MgSO}_{4}$ content of more than $30 \%$ wt (30$\mathrm{MgSO}_{4} / \mathrm{AC}$ and $40-\mathrm{MgSO}_{4} / \mathrm{AC}$ samples). The hydration experiment performed on the 30$\mathrm{MgSO}_{4} / \mathrm{AC}$ sample at $\mathrm{RH}=60 \%$ verified the relation between the salt hydration level and the hydration enthalpy. Higher water partial pressure enhanced water molecule transport and improved salt hydration. The hydration enthalpy of $30-\mathrm{MgSO}_{4} / \mathrm{AC}$ showed an increase from $859 \mathrm{~J} / \mathrm{g}_{\text {dry }}$ material at $\mathrm{RH}=30 \%$ to $1324 \mathrm{~J} / \mathrm{g}_{\text {dry }}$ material at $\mathrm{RH}=60 \%$. After 8 cycles of hydration/dehydration, the $30-\mathrm{MgSO}_{4} / \mathrm{AC}$ sample was practically stable. Furthermore, the 30$\mathrm{MgSO}_{4} / \mathrm{AC}$ ) composite was modelled in two distinct scenarios for house heating and sanitary hot water generation. Finally, the experimentally obtained calorimetric data were used to implement a numerical model. Two different scenarios were considered, the first for heating a
\end{abstract}


house and the second for producing hot sanitary water. Both scenarios show the possibility of using the $\mathrm{MgSO}_{4} / \mathrm{AC}$ composite in a multifunction thermochemical heat storage system.

\section{Introduction}

Fuel consumption will almost certainly double by 2050 , owing to continuous increases in global technology progress [1]. The average use of energy, especially fossil fuels, has increased dramatically as countries are becoming more industrialized and people's standards of living have increased [2,3]. While uncontrolled utilization depletes fossil fuel reserves, it also causes environmental issues such as pollution, greenhouse gas emissions (mainly $\mathrm{CO}_{2}$ ), and global warming. Kelvin et al [4] reported that the anthropogenic emission of $\mathrm{CO}_{2}$ has been the major source of $\mathrm{CO}_{2}$ emissions into the atmosphere, with fossil fuel combustion engines (392 Mt) and coal-fired power plants $(279 \mathrm{Mt})$ as the major contributors.

Global $\mathrm{CO}_{2}$ emissions have been increasing on average in recent years, with $\mathrm{CO}_{2}$ emissions 1.9\% higher in 2019 than in 2018 [4,5]. According to Janssens-Maenhout et al. [6], total global greenhouse gas (GHG) emissions (excluding land-use change) increased by $2 \%$ in 2018 , equivalent to $51.8 \mathrm{Gt}$ of $\mathrm{CO}_{2}$ with an annual growth rate of $1.3 \%$. Global greenhouse gas emissions in 2018 amounted to $55.6 \mathrm{Gt} \mathrm{CO}_{2}$ including those for land-use change. This increase occurred as global economic growth in 2018 increased to an average annual rate of $3.5 \%$, the highest since 2012 [7].

Current emissions of greenhouse gases that exclude those from land-use change today are approximately 57\% higher than in 1990 and $43 \%$ in 2000. $\mathrm{CO}_{2}$ levels are now alarming and indicate the need to take immediate action to prevent serious repercussions from climate change [8]. While, during the Paris Climate Conference (COP21), 195 countries decided to prevent a 
global temperature upsurge of less than $2{ }^{\circ} \mathrm{C}$, it is now fairly common knowledge that $\mathrm{CO}_{2}$ emissions are predicted to increase by over $40 \%$ in 2040 compared with those of 2010 , all due to the increase in energy demand. Hence, finding a renewable and clean fuel source is thus one of the most cost-effective options [2,9].

One of the Paris Agreement's goals is to completely switch away from fossil fuels and toward renewable energy sources. However, the world's renewable energy potential has yet to be completely realized; only $23 \%$ of these energy sources have been used [10]. This opens up a lot of opportunities for strengthening and innovating clean energy policies. According to the U.S. Energy Information Administration's Annual Energy Outlook (AEO) report, renewable energy sources such as solar, wind, and geothermal will account for $20 \%$ of total energy generation by the end of 2020. The main issue with solar and wind energy is their intermittent nature and inability to provide electricity 24 hours a day. As a result, renewable energy storage technologies (REST) that enable a stable energy supply chain are critical.

Thermal heat storage systems for residential applications are currently the focus of much research in order to extend the use of renewable energy resources [11-13]. They help in overcoming the mismatch between the heat source's availability (solar heat, waste heat) and the building's heat requirements [14-16]. The most promising choice among thermal energy storage technologies is thermochemical heat storage, which has the highest energy storage densities and hence the best compactness of the storage system [17]. Due to a lack of available space, this criterion is critical for a residential house [18-20].

The development of new materials and their subsequent application depends on a fundamental understanding of their molecular structure, relating the structure to material properties and performance [21-26]. 
One of the main challenges is to develop new thermochemical materials with high energy storage densities $[27,28]$. The material used for storage is critical. To optimize its performance, its sorption characteristics must precisely match the system's cycle working conditions [29]. Many attempts are being made to produce novel energy storage materials with particular features such as high energy storage density, good multi-cycle stability, non-toxicity, and costeffectiveness [30,31]. Thermochemical heat storage uses a reversible sorption process. Hygroscopic inorganic salts, sorbents, or composite materials can all be used as storage materials. Silica gels [32,33], (AlPOs and SAPOs) [34], activated carbon [35], Metal Organic Frameworks (MOF) materials [36-38], and zeolites [39-41] are the most often used sorbents. Composite materials (hygroscopic salt integrated into the pores of a host matrix) provide interesting characteristics for thermal energy storage applications, with a behavior that falls between inorganic salts and porous host materials. The best feature of these materials is that the matrix reduces the issues associated with salts deliquescence, such as agglomeration, freeflowing, and corrosion [42-44], which can occur when employing pure salts. In composite materials, heat and mass transfers are also improved [45].

A number of salt/matrix combinations have been investigated in the literature. As porous host matrix, sorbents such as zeolites [40,41,46], silica gels [47-49], activated carbons [50], MOF [36,51,52], carbon nanotubes [53], or vermiculite [54] have been investigated. $\mathrm{MgSO}_{4}[41,55]$, $\mathrm{CaCl}_{2}$ [56-58], $\mathrm{LiBr}[50,53,59]$, and $\mathrm{LiCl}[60,61]$ are the most commonly examined inorganic salts.

For example, zeolites are porous materials with a high water affinity, allowing water molecules to be adsorbed on their large internal and external surfaces. Despite having a high energy storage capacity (for $13 \mathrm{X}$ zeolite, equivalent to $131 \mathrm{kWh} / \mathrm{m}^{3}$, [62]), zeolites have a poor thermal conductivity (for $13 \mathrm{X}$ zeolite: $\lambda=0.15 \mathrm{~W} /(\mathrm{m} \mathrm{K})$ ) [63], which may be a issue in some applications (i.e. closed systems requiring heat exchangers). As demonstrated by A. Frazzica 
[44], most zeolites have a charging temperature (dehydration temperature) greater than $150{ }^{\circ} \mathrm{C}$, which might limit their usage in the presence of low temperature heat sources. However, some hygroscopic salts have greater nominal energy storage capacity than zeolites (for example, $\mathrm{SrCl}_{2}, 667 \mathrm{kWh} / \mathrm{m}^{3} ; \mathrm{CaCl}_{2}, 583 \mathrm{kWh} / \mathrm{m}^{3} ; \mathrm{MgSO}_{4}, 583 \mathrm{kWh} / \mathrm{m}^{3} ; \mathrm{MgCl}_{2}, 555 \mathrm{kWh} / \mathrm{m}^{3}$; and $\left.\mathrm{Al}_{2}(\mathrm{SO} 4)_{3}, 444 \mathrm{kWh} / \mathrm{m}^{3}[64]\right)$. Unfortunately, heat and mass transfer issues are frequently observed in these materials. Their poor thermal conductivity and the formation of crusts upon hydration often enable the water molecules diffusion into the solid $[65,66]$.

To fully use the great potential of salt hydrates, mass and heat transfer must be enhanced. An option is then to prepare composite materials, where the salt hydrates are deposited on a porous support. A suitable thermochemical heat storage composite must be capable of being cycled multiple times (many consecutive hydration/dehydration cycles).

The possibility to maintain the heat storage density upon cycling is linked to the possibility to completely rehydrate the salt. It must then be well dispersed and anchored to the support, without the formation of crusts and/or structural changes [67]. The deposition technique is therefore critical to avoid salt aggregation and the obstruction of the support's pores [64]. In certain cases, the salts were deposited on zeolites, which had previously been studied [68]. These investigations revealed that the type of porosity (micro/meso) is an important parameter in composite design. If the pores are too small, the salt might block their entrance, preventing water molecules from diffusing and limiting energy storage capacity. Other materials, such as mesoporous activated carbon or silica-gels, have been demonstrated to be extremely promising supports. The salt may be introduced into their wide pores, enhancing their energy storage capacity and avoiding pore blockage $[45,69]$. Besides the high surface area and the presence of mesoporosity, another important criterion in the choice of the most suitable support is good thermal conductivity. This parameter is crucial for the optimization of the heat transport phenomena. The thermal conductivity of various potential supports is depicted in Fig. 1 Fig. 1 
depicts the thermal conductivity of several potential supports [70,71]. The conductivity measurements showed that activated carbon has a higher conductivity than the other sorbents, reaching $0.75 \mathrm{~W} /(\mathrm{m} \cdot \mathrm{K})$. It is worth noticing that the highest values reported in Fig. 1 represent the intrinsic thermal conductivity of the various materials, and that the thermal conductivity of shaped materials (pellets, spheres, etc.), generally used in real applications, is much lower due to the presence of air between the particles. In any case, selecting a material with a relatively high intrinsic thermal conductivity will reasonably permit to improving that of the final heat storage material once shaped.

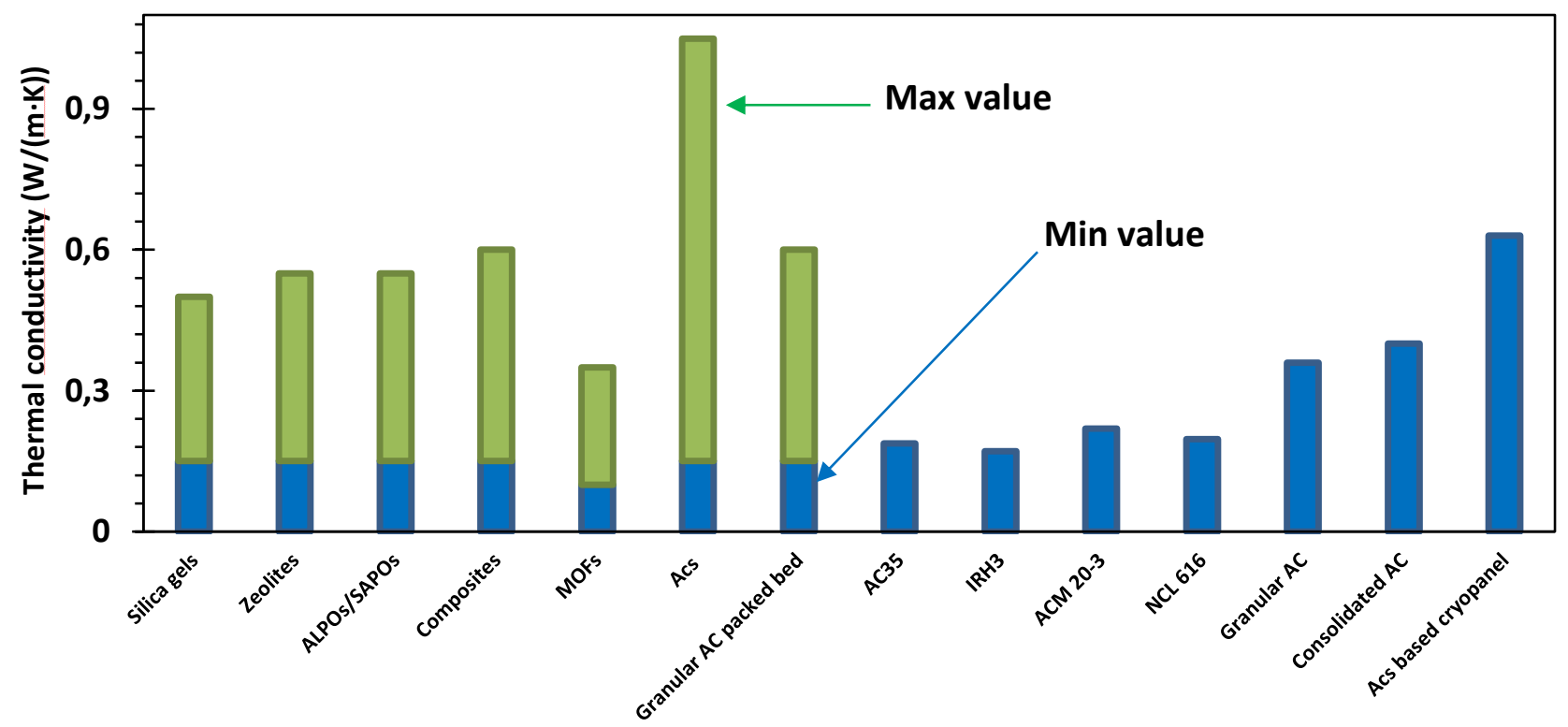

Fig. 1. Intrinsic thermal conductivity of different materials [70-76].

Moreover, the use of activated carbon (AC) in a sorption heat storage offers considerable potential in many respects. On the one hand, the production of AC from fossil coal or biomass is potentially more cost-effective than for the previously predominant material classes like silica gel and zeolite due to the simple production steps. Material costs are significantly more relevant in seasonal heat storage applications than in heat pump applications, especially with a limited number of loading and unloading cycles throughout the system's projected service life. Furthermore, ACs have large porosities and internal surface areas, and their hydrophilicity may 
be adjusted by the choice of starting material and pyrolysis conditions. Furthermore, chemical modifications are possible because of AC's versatile internal surface.

Table 1. Heat storage density of different composites and salt hydrates at different operating conditions

\begin{tabular}{|c|c|c|c|c|c|c|}
\hline Matrixes & Salts & $\begin{array}{c}\text { Salt } \\
(\text { wt. \%) }\end{array}$ & $\begin{array}{c}\text { Preparation } \\
\text { method }\end{array}$ & $\begin{array}{c}\text { Experimental } \\
\text { Conditions }\end{array}$ & $\begin{array}{l}\text { Storage } \\
\text { density }\end{array}$ & Ref. \\
\hline Vermiculite & $\mathrm{CaCl}_{2}$ & 24 & $\begin{array}{c}\text { Wet } \\
\text { impregnation }\end{array}$ & $25-150^{\circ} \mathrm{C}$ & $364.3 \mathrm{~J} / \mathrm{g}$ & [77] \\
\hline Vermiculite & $\mathrm{MgSO}_{4}$ & 24 & $\begin{array}{c}\text { Wet } \\
\text { impregnation }\end{array}$ & $25-150^{\circ} \mathrm{C}$ & $406.5 \mathrm{~J} / \mathrm{g}$ & [77] \\
\hline Vermiculite & $\mathrm{Ca}\left(\mathrm{NO}_{3}\right)_{2}$ & 24 & $\begin{array}{c}\text { Wet } \\
\text { impregnation }\end{array}$ & $25-150^{\circ} \mathrm{C}$ & $215.6 \mathrm{~J} / \mathrm{g}$ & [77] \\
\hline Vermiculite & $\mathrm{Li}\left(\mathrm{NO}_{3}\right)_{2}$ & 24 & $\begin{array}{c}\text { Wet } \\
\text { impregnation }\end{array}$ & $25-150^{\circ} \mathrm{C}$ & $286.9 \mathrm{~J} / \mathrm{g}$ & [77] \\
\hline Vermiculite & $\mathrm{LiBr}$ & 24 & $\begin{array}{c}\text { Wet } \\
\text { impregnation }\end{array}$ & $25-150^{\circ} \mathrm{C}$ & $268.9 \mathrm{~J} / \mathrm{g}$ & [77] \\
\hline $\begin{array}{l}\text { Activated } \\
\text { carbon }\end{array}$ & $\mathrm{CaCl}_{2}$ & 24 & $\begin{array}{c}\text { Wet } \\
\text { impregnation }\end{array}$ & $25-150^{\circ} \mathrm{C}$ & $305.1 \mathrm{~J} / \mathrm{g}$ & [77] \\
\hline Silica gel & $\mathrm{CaCl}_{2}$ & 24 & $\begin{array}{c}\text { Wet } \\
\text { impregnation }\end{array}$ & $25-150^{\circ} \mathrm{C}$ & $123.3 \mathrm{~J} / \mathrm{g}$ & [77] \\
\hline Zeolite 13X & $\mathrm{CaCl}_{2}$ & 24 & $\begin{array}{c}\text { Wet } \\
\text { impregnation }\end{array}$ & $25-150^{\circ} \mathrm{C}$ & $168.1 \mathrm{~J} / \mathrm{g}$ & [77] \\
\hline $\begin{array}{c}\text { Expanded } \\
\text { clay or NZ } \\
\text { pumice }\end{array}$ & $\mathrm{SrCl}_{2}$ & 30 & $\begin{array}{c}\text { Wet } \\
\text { impregnation }\end{array}$ & $\begin{array}{c}128^{\circ} \mathrm{C} \\
\mathrm{RH}=71 \%\end{array}$ & $\begin{array}{c}2.4 \\
\mathrm{GJ} / \mathrm{m}^{3}\end{array}$ & [64] \\
\hline- & $\mathrm{CaCl}_{2}$ & - & $\begin{array}{c}\text { Wet } \\
\text { impregnation }\end{array}$ & $\begin{array}{c}146^{\circ} \mathrm{C}, \\
\mathrm{RH}=30 \%\end{array}$ & $\begin{array}{c}2.1 \\
\mathrm{GJ} / \mathrm{m}^{3}\end{array}$ & {$[64]$} \\
\hline- & $\mathrm{MgSO}_{4}$ & - & $\begin{array}{c}\text { Wet } \\
\text { impregnation }\end{array}$ & $\begin{array}{c}150^{\circ} \mathrm{C}, \\
\mathrm{RH}=90 \%\end{array}$ & $\begin{array}{c}2.1 \\
\mathrm{GJ} / \mathrm{m}^{3}\end{array}$ & [64] \\
\hline- & $\mathrm{MgCl}_{2}$ & - & $\begin{array}{c}\text { Wet } \\
\text { impregnation }\end{array}$ & $\begin{array}{c}230^{\circ} \mathrm{C}, \\
\mathrm{RH}=33 \%\end{array}$ & $\begin{array}{c}2.0 \\
\mathrm{GJ} / \mathrm{m}^{3}\end{array}$ & [64] \\
\hline- & $\mathrm{Al}_{2}\left(\mathrm{SO}_{4}\right)_{3}$ & - & $\begin{array}{c}\text { Wet } \\
\text { impregnation }\end{array}$ & $300^{\circ} \mathrm{C}$ & $\begin{array}{c}1.6 \\
\mathrm{GJ} / \mathrm{m}^{3}\end{array}$ & [64] \\
\hline- & $\begin{array}{c}\mathrm{MgSO}_{4} / \mathrm{ZnSO}_{4} \\
: 9 / 1\end{array}$ & - & $\begin{array}{c}\text { Wet } \\
\text { impregnation }\end{array}$ & $120^{\circ} \mathrm{C}$ & $1422 \mathrm{~J} / \mathrm{g}$ & [78] \\
\hline Zeolite 13X & $\mathrm{MgSO}_{4}$ & 15 & $\begin{array}{c}\text { Wet } \\
\text { impregnation }\end{array}$ & $\begin{array}{l}150^{\circ} \mathrm{C} 4 \mathrm{~h}+ \\
300^{\circ} \mathrm{C} 2 \mathrm{~h}, \\
\mathrm{RH}=80 \%\end{array}$ & $632 \mathrm{~J} / \mathrm{g}$ & [79] \\
\hline- & $\mathrm{CrCl}_{2}$ & - & - & $68^{\circ} \mathrm{C}, 20 \mathrm{mbar}$ & $\begin{array}{c}2.11 \\
\mathrm{GJ} / \mathrm{m}^{3}\end{array}$ & [80] \\
\hline- & $\mathrm{LiCl}$ & - & - & $72^{\circ} \mathrm{C}, 20 \mathrm{mbar}$ & $\begin{array}{c}2.08 \\
\mathrm{GJ} / \mathrm{m}^{3}\end{array}$ & [80] \\
\hline- & $\mathrm{LiBr}$ & - & - & $\begin{array}{c}110^{\circ} \mathrm{C}, 20 \\
\text { mbar }\end{array}$ & $\begin{array}{c}2.01 \\
\mathrm{GJ} / \mathrm{m}^{3}\end{array}$ & [80] \\
\hline- & $\mathrm{FeCl}_{2}$ & - & - & $59^{\circ} \mathrm{C}, 20 \mathrm{mbar}$ & $\begin{array}{c}1.93 \\
\mathrm{GJ} / \mathrm{m}^{3}\end{array}$ & {$[80]$} \\
\hline
\end{tabular}




\begin{tabular}{|c|c|c|c|c|c|c|}
\hline - & $\mathrm{CuCl}_{2}$ & - & - & $59^{\circ} \mathrm{C}, 20 \mathrm{mbar}$ & $\begin{array}{c}1.74 \\
\mathrm{GJ} / \mathrm{m}^{3}\end{array}$ & [80] \\
\hline - & $\mathrm{CaCl}_{2}$ & - & - & $\begin{array}{c}111^{\circ} \mathrm{C}, 20 \\
\text { mbar }\end{array}$ & $\begin{array}{c}1.54 \\
\mathrm{GJ} / \mathrm{m}^{3}\end{array}$ & {$[80]$} \\
\hline- & $\mathrm{Mg}\left(\mathrm{NO}_{3}\right)_{2}$ & - & - & $68^{\circ} \mathrm{C}, 20 \mathrm{mbar}$ & $\begin{array}{c}1.53 \\
\mathrm{GJ} / \mathrm{m}^{3}\end{array}$ & {$[80]$} \\
\hline- & $\mathrm{LiNO}_{2}$ & - & - & $\begin{array}{c}102^{\circ} \mathrm{C}, 20 \\
\text { mbar }\end{array}$ & $\begin{array}{c}1.51 \\
\mathrm{GJ} / \mathrm{m}^{3}\end{array}$ & [80] \\
\hline- & $\mathrm{K}_{2} \mathrm{CO}_{3}$ & - & - & $65^{\circ} \mathrm{C}, 20 \mathrm{mbar}$ & $\begin{array}{c}1.3 \\
\mathrm{GJ} / \mathrm{m}^{3}\end{array}$ & {$[80]$} \\
\hline- & $\mathrm{MgCl}_{2}$ & - & - & $\begin{array}{c}104^{\circ} \mathrm{C}, 20 \\
\text { mbar }\end{array}$ & $\begin{array}{c}1.93 \\
\mathrm{GJ} / \mathrm{m}^{3}\end{array}$ & {$[80]$} \\
\hline
\end{tabular}

To select the best salt for the TES system, the salt must be inexpensive, safe for human health and the environment, thermally stable in the temperature range where it will be used, and, of course, have a high heat storage density (comparison in Table 1). To expand the applications panel, the relative humidity of deliquescence (RHD) of the salt is an important parameter to consider. The RHD is the humidity limit at which the salt will dissolve in the adsorbed water in relation to temperature, the phenomenon of absorption into the material then occurring. Exceeding this limit allows more water to be absorbed and thus increases the amount of heat provided by the reaction. However, the formation of saline solution can cause corrosion problems and can degrade the porous matrix containing the salt [81]. As an example, for temperatures between 10 and $80{ }^{\circ} \mathrm{C}$, the deliquescence process of $\mathrm{MgSO}_{4}, \mathrm{nH}_{2} \mathrm{O}$ will not occur below $80 \%$ relative humidity $(\mathrm{RH})$ because its thermodynamically stable at this range of temperature and humidity $[82,83]$. A good affinity between the impregnated salt and the support is needed to delay the melting and the formation of agglomerates. In previous studies $[64,77-$ 80], salt hydrates were tested under different conditions in order to obtain information on the dehydration temperature range, the optimal relative humidity value for hydration, and to compare the heat storage density values. $\mathrm{MgSO}_{4}$ and $\mathrm{CaCl}_{2}$ are the two most investigated salts [79]. These two salts have been the subject of considerable research [44,66,84-87]. These salts are highly relevant in heat storage systems since they present the highest energy density $(2.8$ 
$\mathrm{GJ} / \mathrm{m}^{3}$ for $\mathrm{MgSO}_{4}$ and $2.1 \mathrm{GJ} / \mathrm{m}^{3}$ for $\left.\mathrm{MgCl}_{2}\right)$ and a low charging temperature $\left(<150{ }^{\circ} \mathrm{C}\right)$, which is suitable for building applications with solar collectors

For all the above-mentioned reasons, novel composite materials obtained by depositing $\mathrm{MgSO}_{4}$ on an AC support were developed, thoroughly characterized, and tested in order to achieve materials with good salt dispersion over the support surface. The goal was to produce materials that were stable throughout the cycles (to maintain a good energy storage capacity), and had a relatively higher thermal conductivity when compared to usual heat storage materials. Finally, the experimental data obtained by performing hydration/dehydration cycles and physicochemical characterizations has been implemented in a numerical model. Following that, several scenarios involving the usage of such material in building applications were simulated.

\section{Experimental}

\subsection{Material preparation}

The carbon material chosen as support was an activated carbon (AC) L27W from Norit N.V (Amersfoort, Netherlands), chemically activated by phosphoric acid for enhancing the mesoporosity. First, the AC was rinsed and filtrated several times on a Buchner funnel with abundant water to eliminate the residual phosphoric acid, until the $\mathrm{pH}$ of the filtrated water was constant $(\mathrm{pH}=5.8)$. Then, the powder was dried in a stove at $100^{\circ} \mathrm{C}$ for 12 hours until complete dehydration. Successively, $\mathrm{MgSO}_{4} \cdot 7 \mathrm{H}_{2} \mathrm{O}$, from Sigma-Aldrich was deposited at different loading (from 5 to 50 wt.\% of $\mathrm{MgSO}_{4}$ ) on the AC support by Incipient Wetness Impregnation 
(IWI). The obtained composites were dried during 12 hours at $100^{\circ} \mathrm{C}$ and labelled as reported in Table 2.

\subsection{Characterization of the samples}

X-Ray Diffraction (XRD) analyses were performed on the compacted powder of the samples on a diffractometer X'Celerator, equipped with a real-time multiple strip detector. The XRD phenomenon is based on constructive interference between monochromatic X-rays and crystalline samples. X-rays were generated by a cathode ray tube, filtered to get monochromatic rays, assembled to concentrate and then directed towards the sample [88-90]. operating with an angular aperture of $2.12^{\circ} 2 \theta$ in the $3^{\circ}$ to $50^{\circ} 2 \theta$ range, and $\mathrm{CuK} \alpha$ radiation with a wavelength of $0.15406 \mathrm{~nm}$. Diffractograms were recorded at room temperature with a step size of $0.017^{\circ} 2 \theta$ and a scan time of $4 \mathrm{~s}$ per step.

A wavelength dispersion X-Ray Fluorescence (XRF) spectrometer (from PANalytical, Zetium) was used to perform the XRF measurements on pellets made of $0.1 \mathrm{~g}$ of the sample and $0.2 \mathrm{~g}$ of binder (boric acid, $\mathrm{H}_{3} \mathrm{BO}_{3}$ ) powder.

High-resolution micrographies were acquired by a Scanning Electron Microscope (SEM) from Philips, XL30 model to observe the morphology of AC [88] and composites and to determine the elemental analysis of activated carbon and the distribution of deposited salt. Prior to analysis, the samples were coated with carbon in order to create a thin conductive layer to improve the quality of the images. The semi-quantitative chemical analysis and atomic composition mapping of the sample were performed by means of Energy Dispersive X-ray (EDX).

The thermal conductivity $\left(\lambda=90 \pm 8 \mathrm{mWm}^{-1} \mathrm{~K}^{-1}\right)$ and the heat capacity $\left(\rho \mathrm{Cp}=307 \pm 26 \mathrm{~kJ} \mathrm{~m}^{-}\right.$ $\left.{ }^{3} \mathrm{~K}^{-1}\right)$ of the samples were determined starting from the values of thermal diffusivity $(\alpha=2.9$ $\left.\pm 0.410^{-7} \mathrm{~m}^{2} \mathrm{~s}^{-1}\right)$ and thermal effusivity $\left(\mathrm{E}=166 \pm 8 \mathrm{Wm}^{-2} \mathrm{~K}^{-1} \mathrm{~s}^{0.5}\right)$ obtained by a Hot Disk TPS 
500 analyzer. The sample' pellets were placed in a covered sample holder where the Kapton sensor was horizontally placed between two layers of the material. The experiments were conducted at $20{ }^{\circ} \mathrm{C}$ for $160 \mathrm{~s}$ at a heating power of $100 \mathrm{~W}$. Each measurement was repeated at least 5 times.

Nitrogen adsorption/desorption isotherms at $-198{ }^{\circ} \mathrm{C}$ were acquired in a ASAP 2420 device from Micrometrics. The samples were previously degassed at room temperature overnight, and then at $120^{\circ} \mathrm{C}$ for 12 hours before analysis [88]. The specific surface area was calculated by applying the Brunauer, Emmett, and Teller (BET) equation, and the porous volume was determined by Density Functional Theory (DFT) calculations.

\subsection{Hydration/dehydration cycling and heat storage density determination}

A Sensys Evo TG-DSC (Thermogravimetry coupled to differential scanning calorimetry) apparatus, equipped with a Wetsys flow humidity generator (from Setaram) was used to measure the heat and the water adsorption/desorption capacities of the composites and verify the cycling (see Fig. 2).
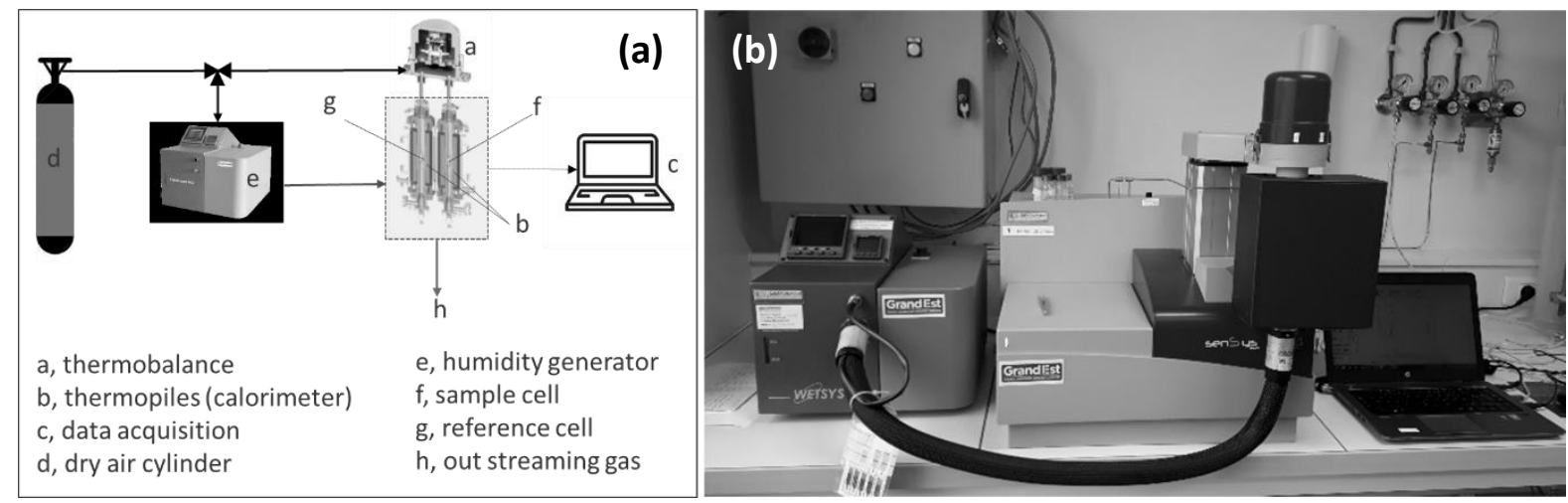

Fig. 2. Schema (a) and photo (b) of the TG-DSC-WETSYS set-up

The procedure was divided into three steps (Fig. 3). First, the composite was totally dehydrated at $300{ }^{\circ} \mathrm{C}$ by raising the temperature from 30 to $300{ }^{\circ} \mathrm{C}$ with a ramp of $10{ }^{\circ} \mathrm{C} / \mathrm{min}$ 
under a flow of dry air $(30 \mathrm{~mL} / \mathrm{min})$, followed by a 30 -minute isotherm at $300{ }^{\circ} \mathrm{C}$. Then, the sample was cooled down at $30{ }^{\circ} \mathrm{C}$ and, once the temperature stabilized at $30{ }^{\circ} \mathrm{C}$, the relative humidity of the air flow was increased to the desired value ( $\mathrm{RH}=30$ or $60 \%)$. The hydration step was prolonged for 20 hours in order to completely rehydrate the material. Finally, the sample was heated-up to $300{ }^{\circ} \mathrm{C}$ at $5{ }^{\circ} \mathrm{C} / \mathrm{min}$. After the 30 -minute of isothermal step, the sample was cooled to $30^{\circ} \mathrm{C}$ and cycled a certain number of times.

Fig. 3 schematically summarizes the dehydration/hydration/dehydration cycle. For the composite containing $30 \mathrm{wt} . \%$ of $\mathrm{MgSO}_{4}$, similar experiments were carried out by performing several successive cycles (with 7 hours' hydration steps) with a pre-treatment performed at 150 ${ }^{\circ} \mathrm{C}$, in order to study its stability over cycling.

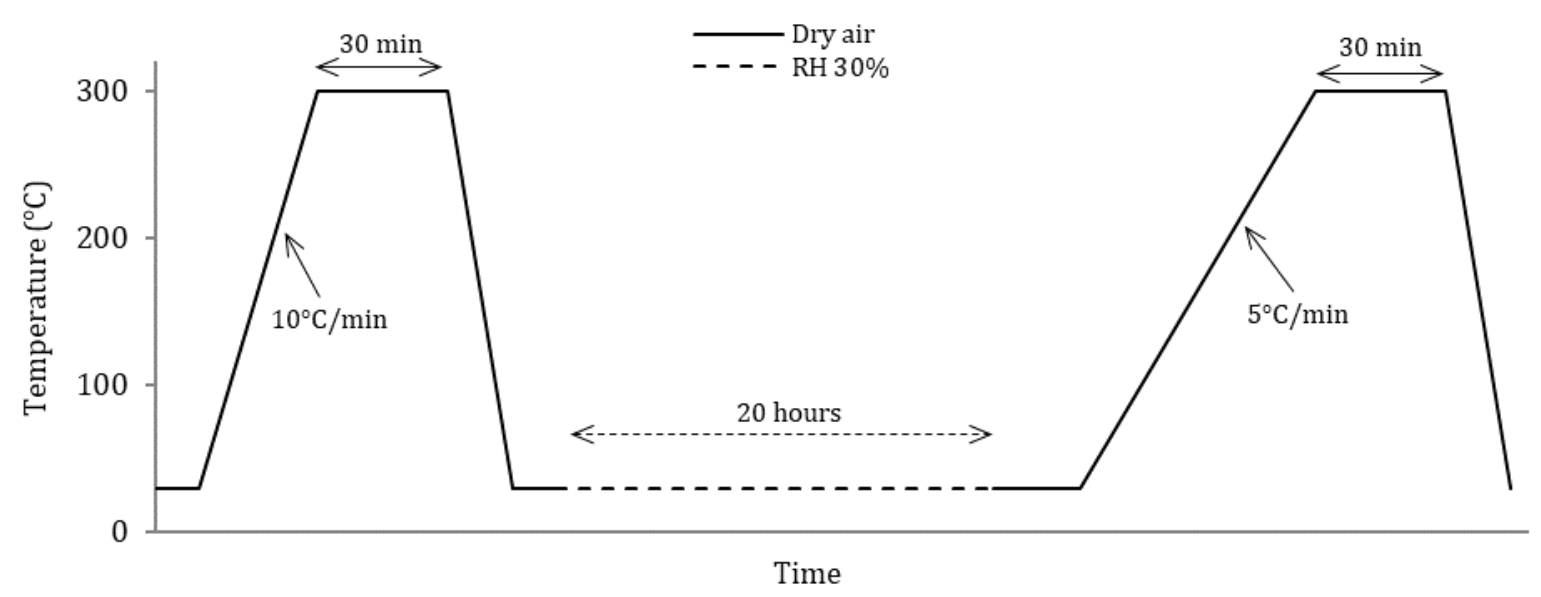

Fig. 3. Thermal cycle used for the TG-DSC-WETSYS analyses (Time not at scale)

\subsection{Simulation of domestic application scenarios}

The system operation was simulated using two scenarios, depending on the implementation of the $\mathrm{MgSO}_{4} / \mathrm{AC}$ composites. The first concerned using the system for winter heating, while the second concerned producing residential hot water in the summer. For this purpose, the simulations have been performed on the basis of a $100 \mathrm{~m}^{2}$ passive house, which requires an air exchange of $250 \mathrm{~m}^{3} / \mathrm{h}$ (double flow mechanical ventilation system). The entire or a part of this flowrate $\left(Q_{\text {inlet }}\right)$ was used in the model for heat generation. The indoor air was assumed to be at 
$\mathrm{T}_{0}=20^{\circ} \mathrm{C}, \mathrm{RH}=70 \%$ (i.e. $\mathrm{X}_{\mathrm{w}}(\mathrm{z}=0)=\mathrm{X}_{0}=10.2 \mathrm{~g} / \mathrm{kg}_{\text {d.a. }}$ ) in winter, and at $\mathrm{T}_{0}=25^{\circ} \mathrm{C}, \mathrm{RH}=70 \%$

(i.e. $\mathrm{X}_{\mathrm{w}}(\mathrm{z}=0)=\mathrm{X}_{0}=13.9 \mathrm{~g} / \mathrm{kg}_{\text {d.a. }}$ ) in summer. To supply sufficient heat for winter heating, a cylindrical reactor ( $1 \mathrm{~m}$ in length and $0.94 \mathrm{~m}$ in radius) containing $1000 \mathrm{~kg}$ of composite was modeled. The cylindrical geometry of the reactor was chosen to simplify the filling of the adsorbent material and maintain consistency with a real application [91]. The fluid was assumed to be perfectly mixed at the reactor's inlet. The airflow was assumed to be laminar and onedimensional.

A set of equations composed of 5 partial differential equations (eq 1 to 5 , detailed in section 3.4) and 3 algebraic equations (air density, air density derivative, and reaction heat) were used to model the system. The differential equations have been spatially discretized by using the finite difference method in order to get an algebraic system of 8 equations, which were solved for each time interval (explicit Euler method). Thus, the system was directly solved. The program was written in Fortran-90.

\section{Results and discussion}

\subsection{Composition, thermal conductivity, structure, and morphology of the composites}

Six composites with a $\mathrm{MgSO}_{4}$ content in the 4-43 wt.\% interval were prepared by incipient wetness impregnation. The elemental composition was determined by XRF in order to verify if the magnesium sulfate content corresponded to the theoretical. Moreover, the phosphor residue of the parent AC was also measured (Table 2).

The experimental values are in agreement with the theoretical values for composites with low $\mathrm{MgSO}_{4}$ content. Otherwise, when the theoretical salt content value was higher, the measured $\mathrm{MgSO}_{4}$ concentration value was lower than expected. These results might be related to matrix inaccuracy in the XRF calibration curve. Indeed, the XRF calibration was based on 
conventional carbon materials and might deviate in the case of a high concentration of salt (starting from the sample containing $30 \mathrm{wt} . \%$ of $\mathrm{MgSO}_{4}$ ).

Table 2. Samples composition, surface area and porosity

\section{Composition (wt.\%)}

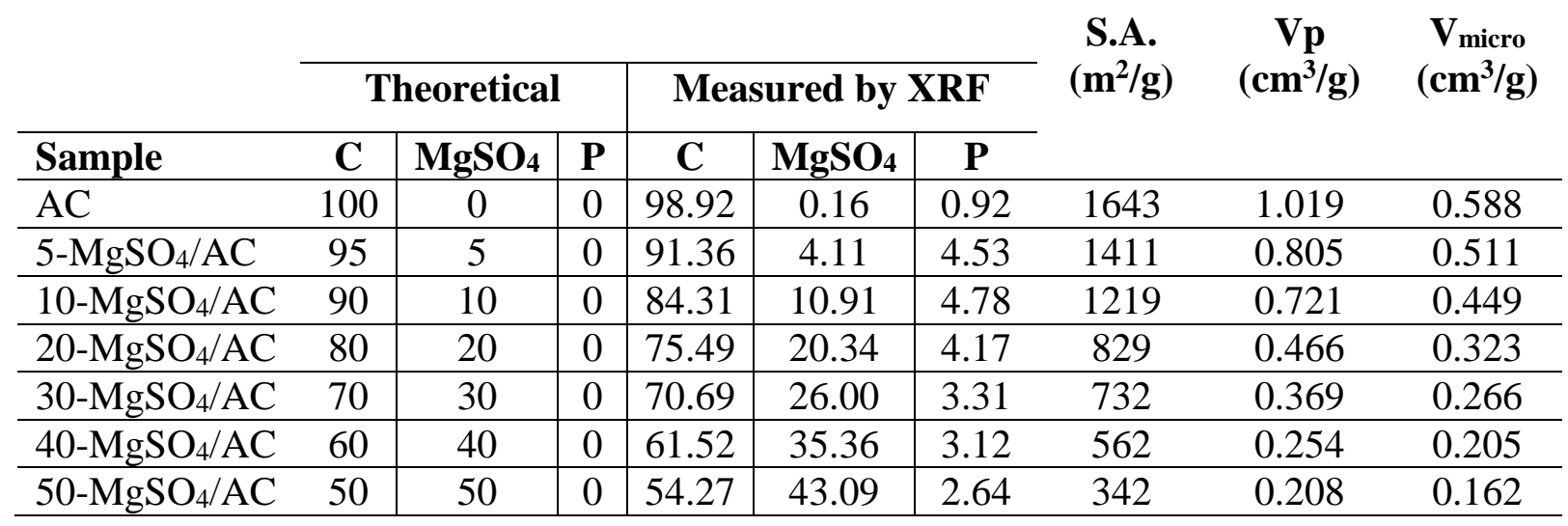

A second possible explanation is the presence of residues of phosphoric acid that have not been completely eliminated by the washing prior to deposition. Indeed, XRF analysis carried out on the samples shows P-contents of between $2.6 \mathrm{wt} . \%$ and $4.8 \mathrm{wt} . \%$.

The thermal conductivity $(\lambda)$ was estimated starting from the measure of the thermal diffusivity determined by hot-disk $(\lambda=\alpha \cdot \rho \cdot \mathrm{Cp}$, where $\alpha$ is the thermal diffusivity, $\rho$ the bulk density, and $\mathrm{C}_{\mathrm{p}}$ the specific heat, respectively). The measured thermal conductivity for bare active carbon was $0.26 \mathrm{~W} /(\mathrm{m} \cdot \mathrm{K})$ (for a measured $\alpha=2.20 \cdot 10^{-7} \mathrm{~m}^{2} / \mathrm{s}$ ), $0.53 \mathrm{~W} /(\mathrm{m} \cdot \mathrm{K})$ for magnesium sulfate heptahydrate salt (for a measured $\alpha=1.60 \cdot 10^{-7} \mathrm{~m}^{2} / \mathrm{s}$ ), and to $0.43 \mathrm{~W} /\left(\mathrm{m} \cdot \mathrm{K}\right.$ ) for $30-\mathrm{MgSO}_{4} / \mathrm{AC}$ composite (for a measured $\alpha=2.21 \cdot 10^{-7} \mathrm{~m}^{2} / \mathrm{s}$ ). The $\mathrm{C}_{\mathrm{p}}$ values considered in the calculation of $\lambda$ were of $1300 \mathrm{~J} /(\mathrm{kg} \cdot \mathrm{K})$ for the AC [92] and $1556 \mathrm{~J} /(\mathrm{kg} \cdot \mathrm{K})$ for the salt [93]. The bulk density ( $\rho$ ) has been experimentally determined by weighing a known volume of the materials; it was found to be, respectively, equal to $895 \mathrm{~kg} / \mathrm{m}^{3}$ for the $\mathrm{AC}$ and $1878 \mathrm{~kg} / \mathrm{m}^{3}$ for $\mathrm{MgSO}_{4} \cdot 7 \mathrm{H}_{2} \mathrm{O}$. The results obtained for the salt are comparable to those reported in the literature (and confirm the reliability of the used methodology [94]. The composite presented a relatively high thermal conductivity 
when compared to other composites reported in the literature (see Fig.1). This value is particularly high because it is measured on the shaped sample (cylindrical pellets), and represents the true value of the heat storage materials that will be potentially charged in a real storage system.

All composites and the bare support have been observed by SEM. The homogeneity of the salt deposition was verified for the various composites. The eventual presence of a crust of salt on the surface was also investigated, as previously observed on composites prepared on different porous supports [41].
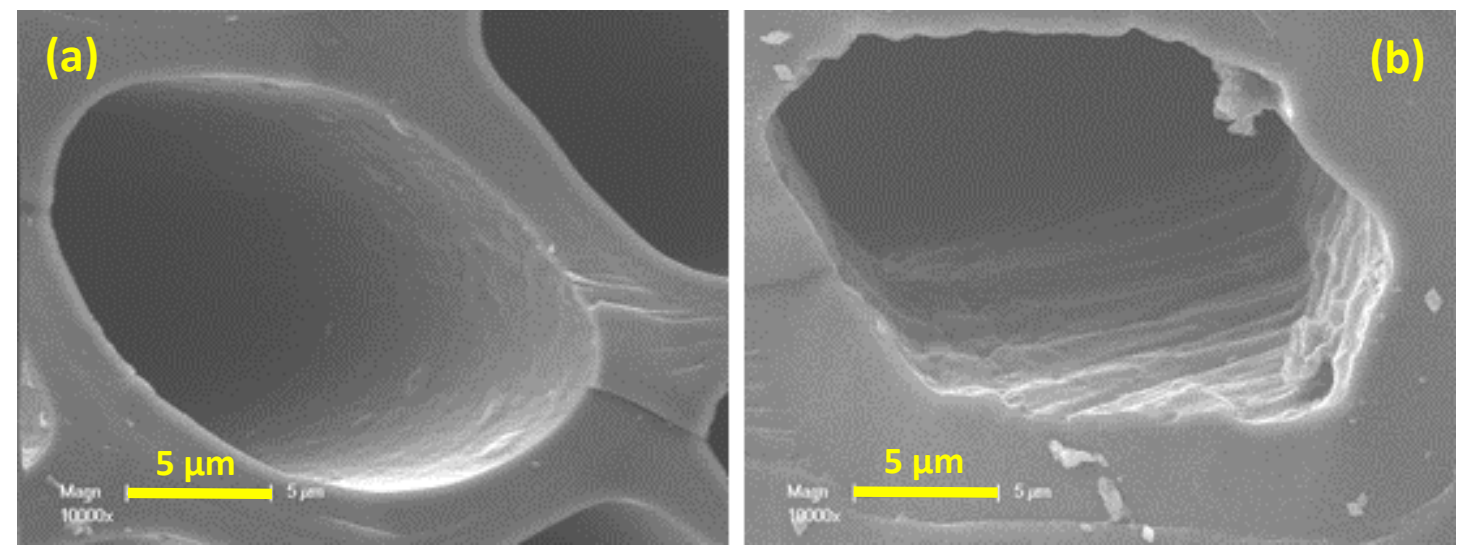

Fig. 4. (a) SEM picture of the activated carbon and (b) SEM picture of the activated carbon impregnated with $30 \%$ of $\mathrm{MgSO}_{4}\left(30-\mathrm{MgSO}_{4} / \mathrm{AC}\right.$.

Observing the micrographies reported in Fig. 4, no large crystallites can be seen on the composite containing $30 \mathrm{wt}$ \% of magnesium sulfate (Fig.4b); no substantial differences can be observed when compared to with the SEM micrographies of the parent activated carbon (Fig. 4a). The salt deposition is uniform, and no macroscopic aggregates are visible on the composite surface or in the macropores' entrance. 

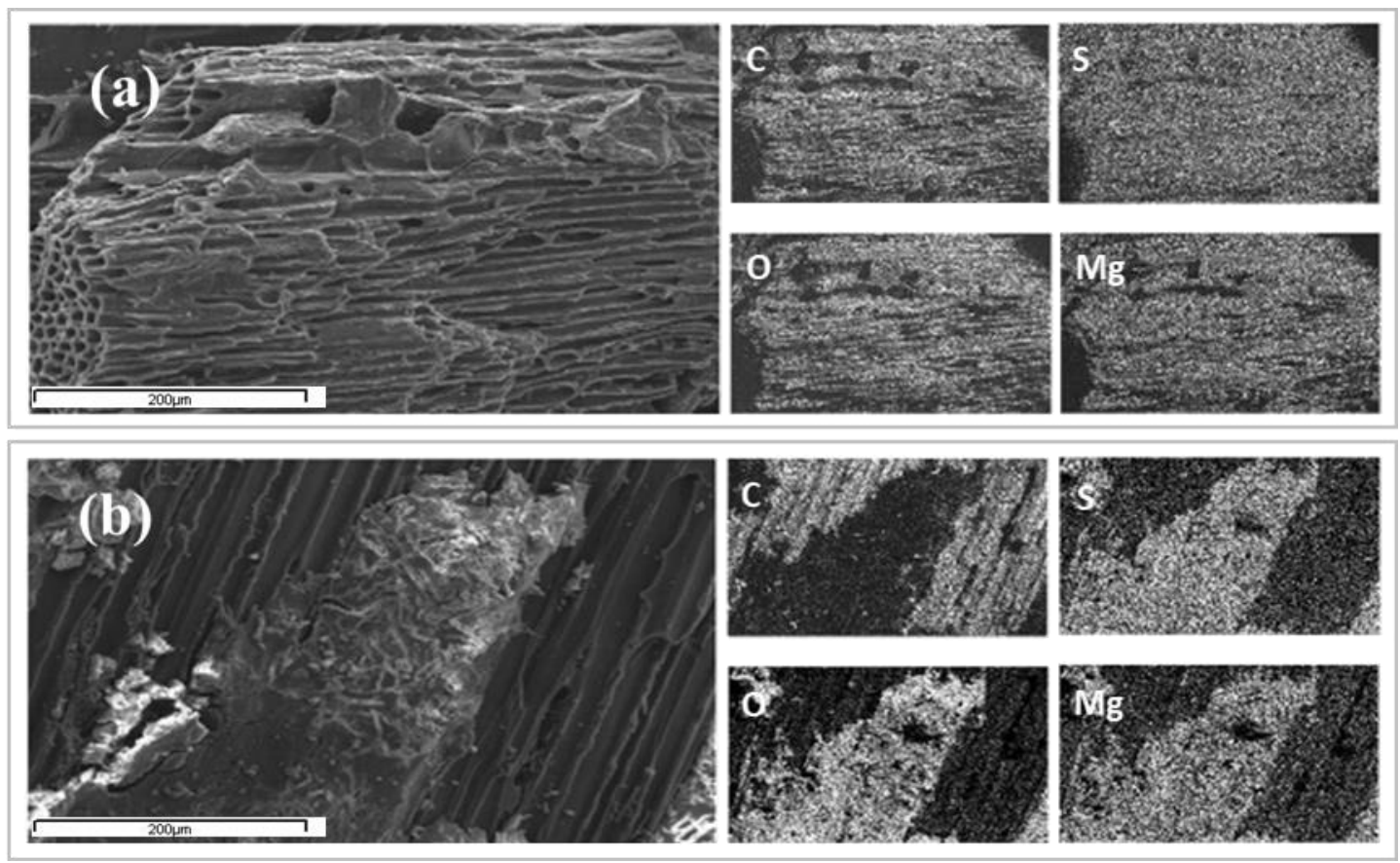

Fig. 5. (a): SEM picture (left) of 40-MgSO $4 / \mathrm{AC}$ composite and its EDX mapping pictures in right hand ( $\mathrm{C}, \mathrm{S}, \mathrm{O}$, and $\mathrm{Mg}$ content); (b): SEM picture (left) of 50-MgSO $4 / \mathrm{AC}$ composite and its EDX mapping pictures in right hand ( $\mathrm{C}, \mathrm{S}, \mathrm{O}$, and $\mathrm{Mg}$ content)

A mapping of the elements present in the samples was performed by EDX; the results for the samples containing 40 and 50 wt.\% of $\mathrm{MgSO}_{4}$ are shown in Fig. 5. The uniformity of the impregnation of the salt on the carbon support can be confirmed for the $40-\mathrm{MgSO}_{4} / \mathrm{AC}$ composite (Fig. 5a). In the four cartographies, each analyzed element $(\mathrm{C}, \mathrm{S}, \mathrm{O}$, and $\mathrm{Mg}$ ) is dispersed in uniform layers. Otherwise, for $50-\mathrm{MgSO}_{4} / \mathrm{AC}$ (Fig. 5b), zones rich in $\mathrm{Mg}, \mathrm{S}$, and O (light colors) can be differentiated from the carbon support (dark zones) due to the presence of crystallites of $\mathrm{MgSO}_{4}$ segregated on the support. The presence of such aggregates can cause different problems, for example, the blocking of the AC pores and the formation of salt crusts. Therefore, both phenomena contribute to the decrease of the mass transfer performance of the material (i.e. water molecules diffusion during the hydration/dehydration process). 


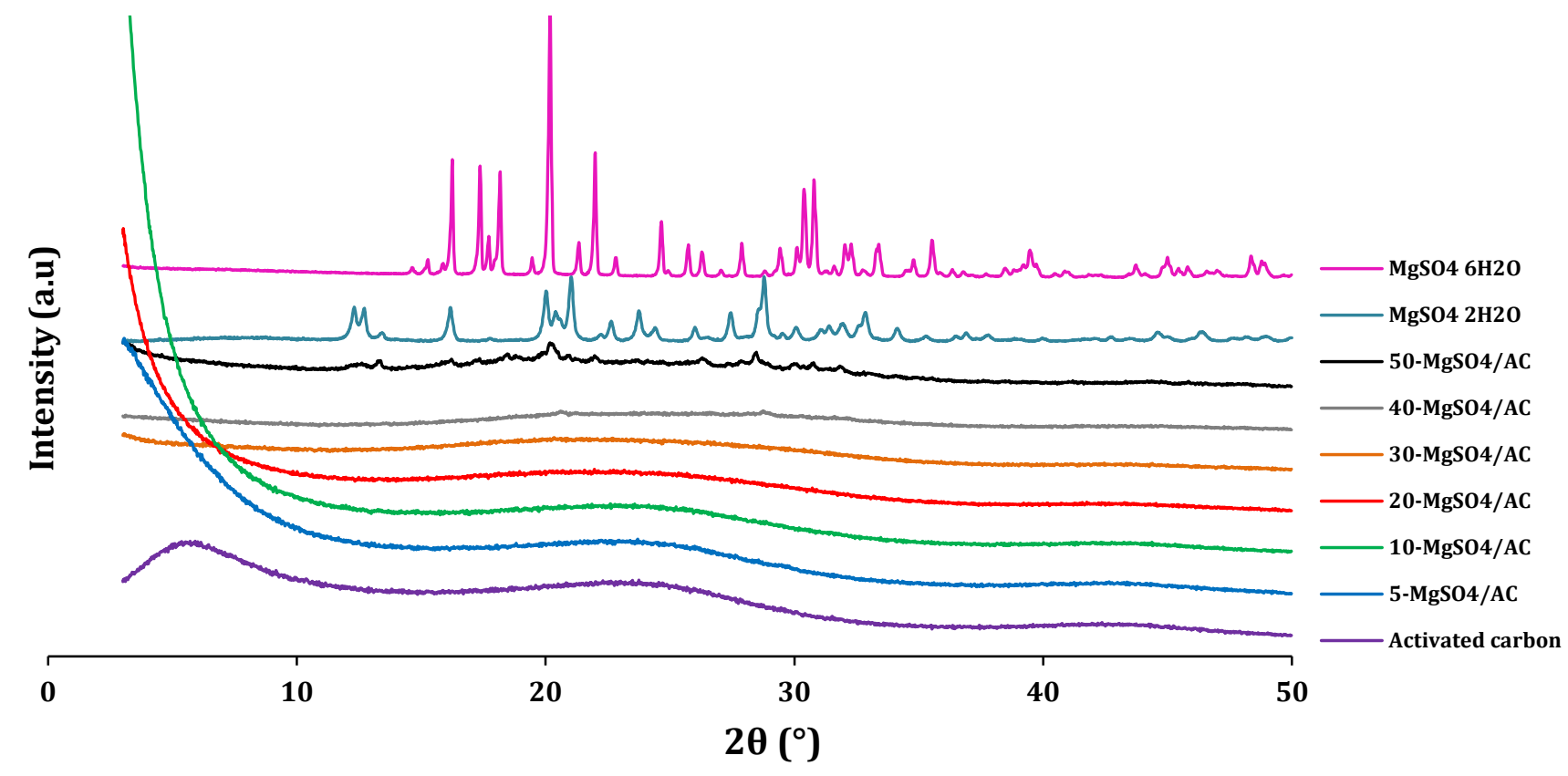

Fig. 6. XRD diffractogram of activated carbon, $\mathrm{MgSO}_{4}$ salts, and all prepared composite samples dried at $150^{\circ} \mathrm{C}$ for 3 hours.

The SEM+EDX analyses were confirmed by the XRD analysis of the samples (Fig. 6). The XRD pattern of AC showed an amorphous structure with two broad peaks at $17^{\circ}$ and $23^{\circ}$, which are characteristic of amorphous carbon. No peaks related to crystallized magnesium sulfate are visible on the samples containing up to $30 \mathrm{wt} . \%$ of $\mathrm{MgSO}_{4}$. For the $40-\mathrm{MgSO}_{4} / \mathrm{AC}$ sample, crystallization begins, and two small peaks assigned to $\mathrm{MgSO}_{4}$ can be observed at 21 and 29 ${ }^{\circ} 2 \theta$. The salt present in the $50-\mathrm{MgSO}_{4} / \mathrm{AC}$ sample is highly crystallized, as already observed by the presence of aggregates visualized by SEM analysis. The pattern of the $50-\mathrm{MgSO}_{4} / \mathrm{AC}$ sample mainly corresponds to that of $\mathrm{MgSO}_{4} \cdot 2 \mathrm{H}_{2} \mathrm{O}$, reported in Fig. 5 for comparison. In order to investigate the impact of the salt deposition on the porosity of the various composites, $\mathrm{N}_{2}$-adsorption at $-198{ }^{\circ} \mathrm{C}$ was performed (Fig. 7). 


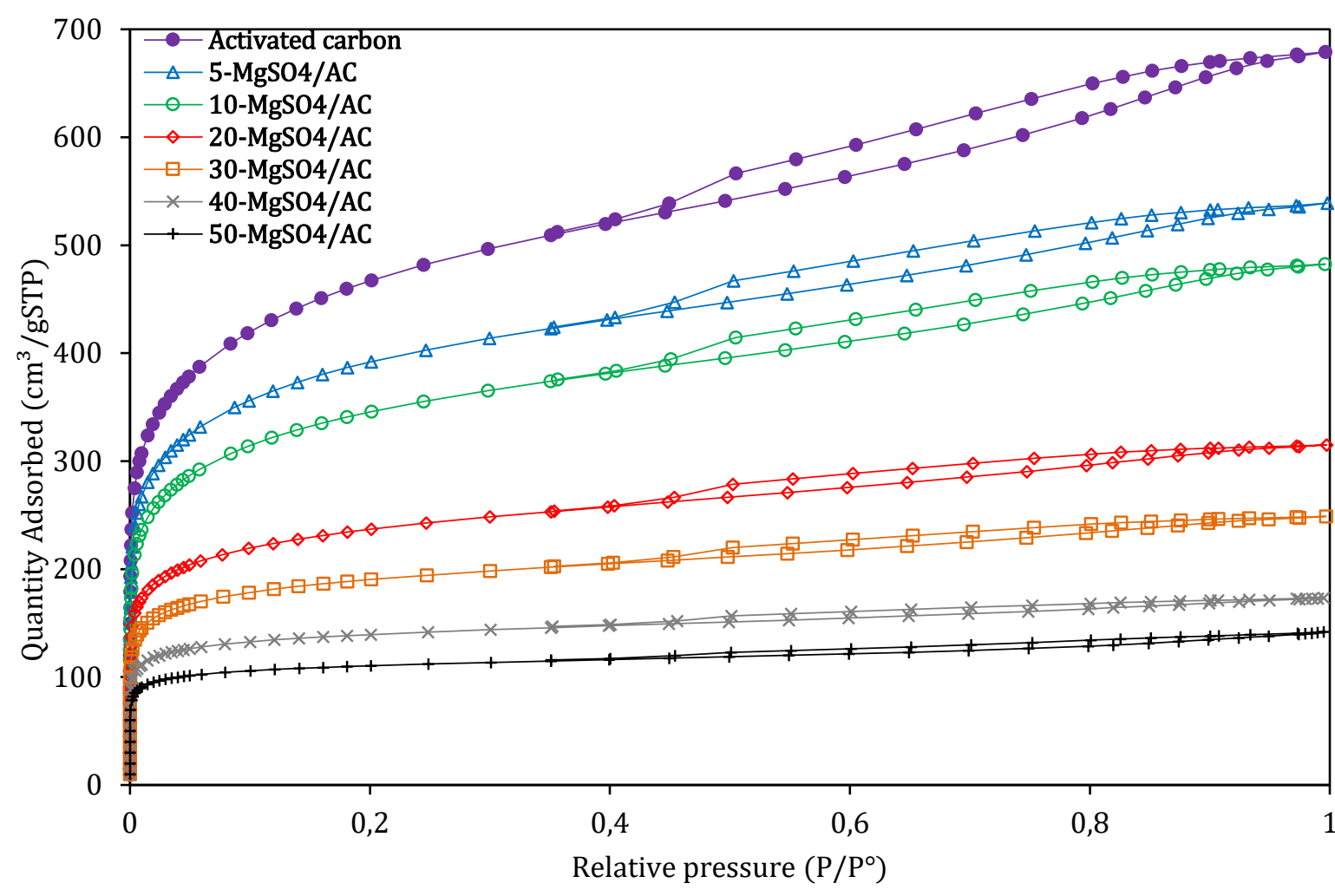

Fig. 7. $N_{2}$ adsorption-desorption isotherms of activated carbon and all prepared composites.

Information on the microstructure of the samples can be deduced by analyzing the shape of the curves and the hysteresis of the nitrogen physisorption isotherms, by referring to the IUPAC classification [95]. For the low magnesium sulfate-containing samples, the hysteresis is quite pronounced, but, even if less visible, its shape does not vary for all the samples. The isotherm shape is of type I (Fig. 7), typical of microporous samples (like activated carbons and molecular sieves) characterized by a relatively small external surface, for which the limiting nitrogen uptake is driven by the micropores' accessibility. In addition, isotherms presented an H4 type hysteresis loop.

Fig. 8 shows the pore distribution of the samples. All composites maintain the distribution as the parent active carbon after the addition of $\mathrm{MgSO}_{4}$. 


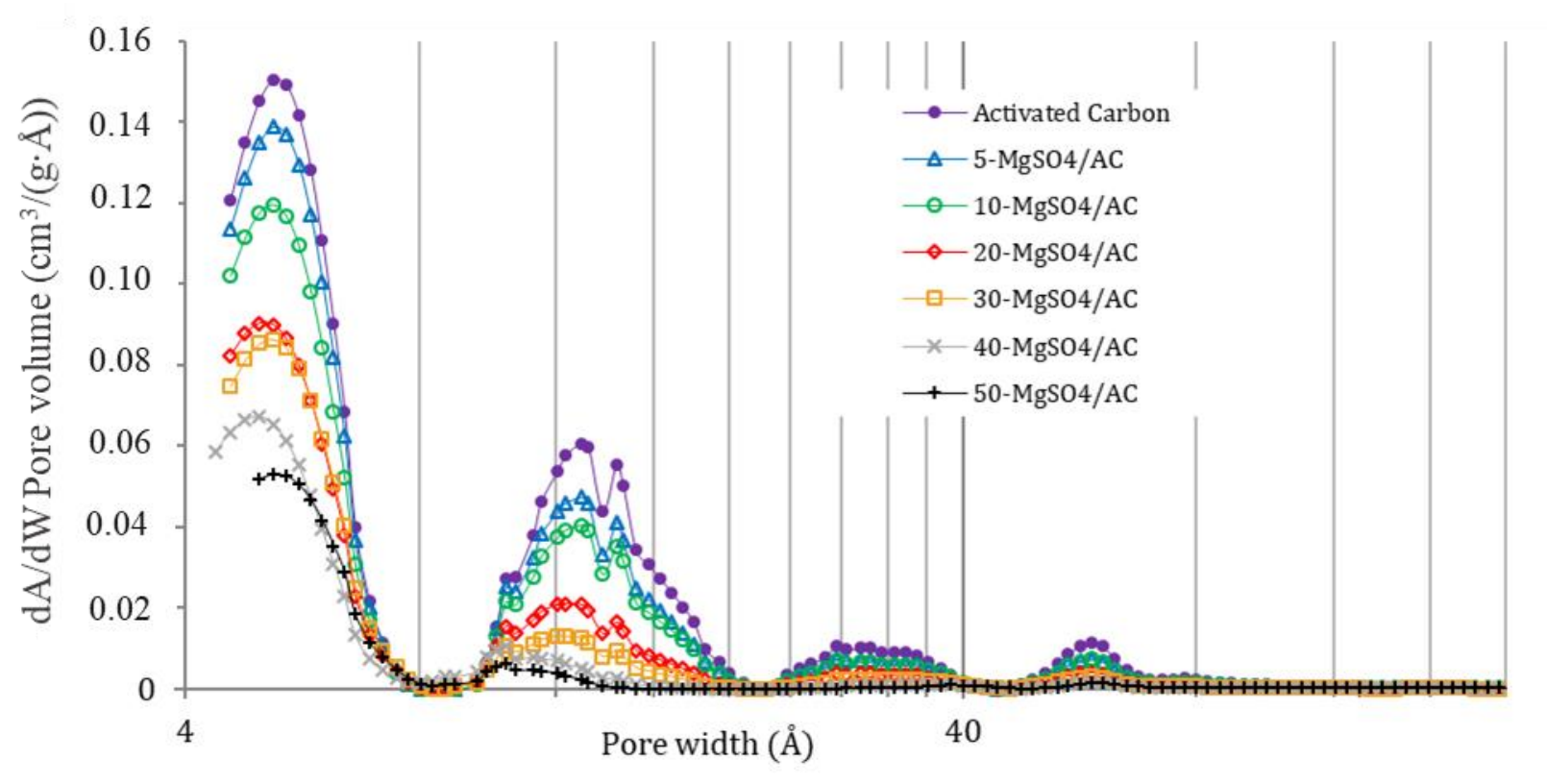

Fig. 8. Pore volume distribution vs. pore width of activated carbon and all prepared composites

The samples are mostly micro- and mesoporous (pore diameters of $<20 \AA$ and from 20-500 , respectively. A smaller fraction of macropores (pore diameters $>500 \AA$ ) is also observed. The porous volume decreases by increasing the quantity of salt deposited. Indeed, magnesium sulfate prevalently blocks access to micropores and mesopores. For instance, bare activated carbon, for example had a microporous volume of $0.145 \mathrm{~cm}^{3} /(\mathrm{g} \cdot \AA)$, while the $50-\mathrm{MgSO}_{4} / \mathrm{AC}$ sample had a pore volume of only $0.052 \mathrm{~cm}^{3} /(\mathrm{g} \cdot \AA)$, which was 3 times lower (see Table 2 ). Macropores are definitely less affected by salt deposition.

Fig. 9 shows the inverse correlation between the pore volume and the surface area as a function of the magnesium sulfate content. The two curves follow almost the same decreasing trend; the lower surface area is related to the blockage of the pores and to the impossibility of the nitrogen molecule to adsorb on the internal surface. The decrease in surface area can also diminish the surface available for water adsorption during the hydration/dehydration processes and diminish the heat storage capacity of the material. A compromise between the amount of salt deposited and the maintain of the specific surface area and porosity is then crucial for the design of these 
composites. This point has been then further investigated by measuring the water sorption and heat storage capacities, as reported in the next section.

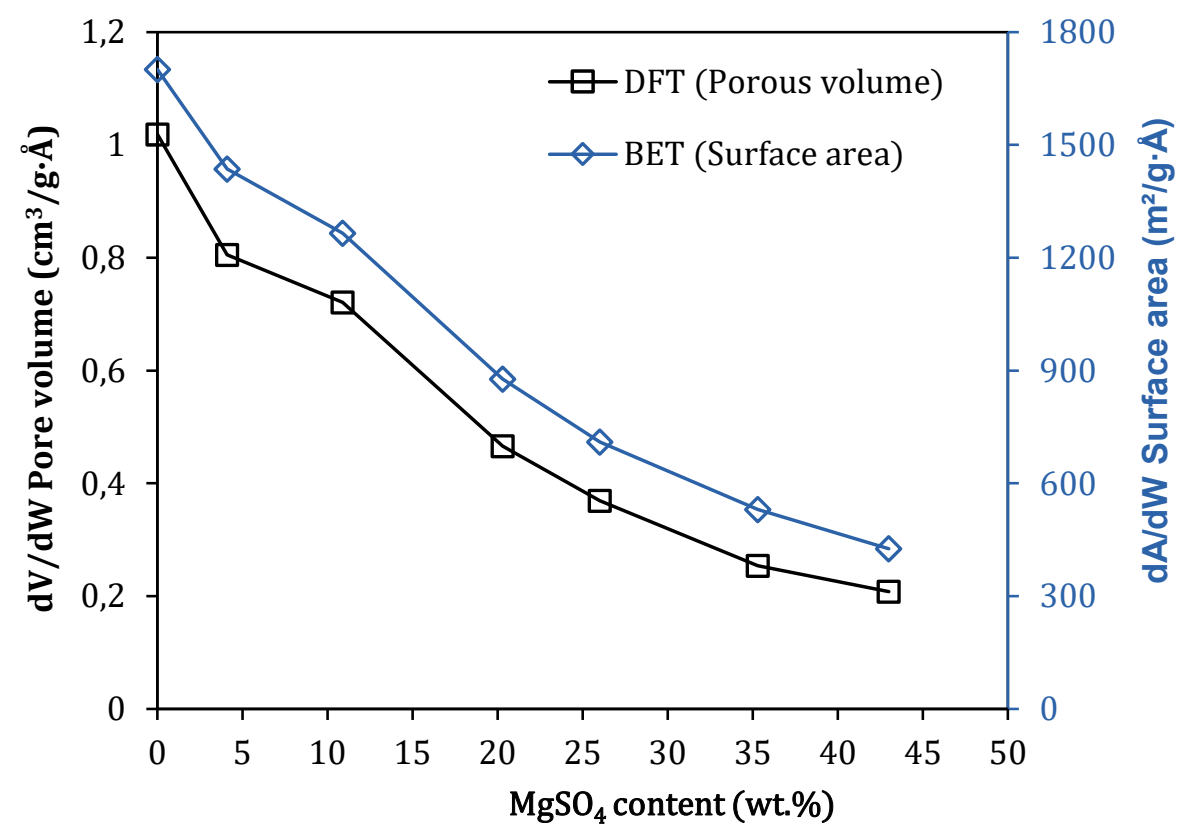

Fig. 9. Effect of $\mathrm{MgSO}_{4}$ content deposited into activated carbon on total pore volume and surface area of each studied sample

\subsection{Heat and water sorption capacity}

The heat and water sorption capacities of the various composites were measured in the TGDSC-Wetsys coupling described in Section 2.2. The calorimetric hydration peaks (here reported as an example for the $30-\mathrm{MgSO}_{4} / \mathrm{AC}$ sample) obtained during water uptake under air flow with a relative humidity (RH) of 30 and $60 \%$ are respectively reported in fig. 10 and 11 . The integration of the surface of the peak represents the heat released (in $\mathrm{kJ} / \mathrm{kg}^{-1}$ dry material), lately reported on the left Y-axes of Fig. 12, for comparing all composites after hydration at $30 \% \mathrm{RH}$ (and $60 \% \mathrm{RH}$ for $30-\mathrm{MgSO}_{4} / \mathrm{AC}$ only). The hydration heat values have an uncertainty of approximately $\pm 15 \mathrm{~kJ} / \mathrm{kg}^{-1}$ dry material.

The integration of the sections of the calorimetric curve at different times of adsorption permits the determination of the interaction energy between the water molecules and the sorbent (i.e. the composite). These values (expressed in $\mathrm{kJ} / \mathrm{mol}_{\mathrm{H} 2 \mathrm{O}}$ ) are reported on the right $\mathrm{Y}$-axes of Figs. 
10,11 , and 12 . The water molecules adsorbed on the composite surface with decreasing energy with the progress of the sample hydration: the related points present a decreasing behavior. The energy of water molecule adsorption on the composites at different coverage extents (corresponding to different time intervals), and represented by the diamond-shaped symbols, varies from 65 (for the first fraction of water molecules adsorbed) to $20 \mathrm{~kJ} / \mathrm{mol}_{\mathrm{H} 2 \mathrm{O}}$ (for the water molecules just physisorbed on the composite). These values are the average over the intervals considered; the first water molecules react with the salt with a high enthalpy of adsorption. For this reason, the total enthalpy of hydration expressed in $\mathrm{kJ} / \mathrm{mol}_{\mathrm{H} 2 \mathrm{O}}$ calculated over the entire hydration process is higher for the composites containing the smallest amount of $\mathrm{MgSO}_{4}$ (Fig. 12). These composites (5- $\mathrm{MgSO}_{4} / \mathrm{AC}$ and $\left.10-\mathrm{MgSO}_{4} / \mathrm{AC}\right)$ present on their surface thin layers of salt (as previously observed by SEM and XRD analysis) that can be easily and completely be hydrated, therefore exploiting the intrinsic heat storage capacity of the salt (high hydration enthalpy).

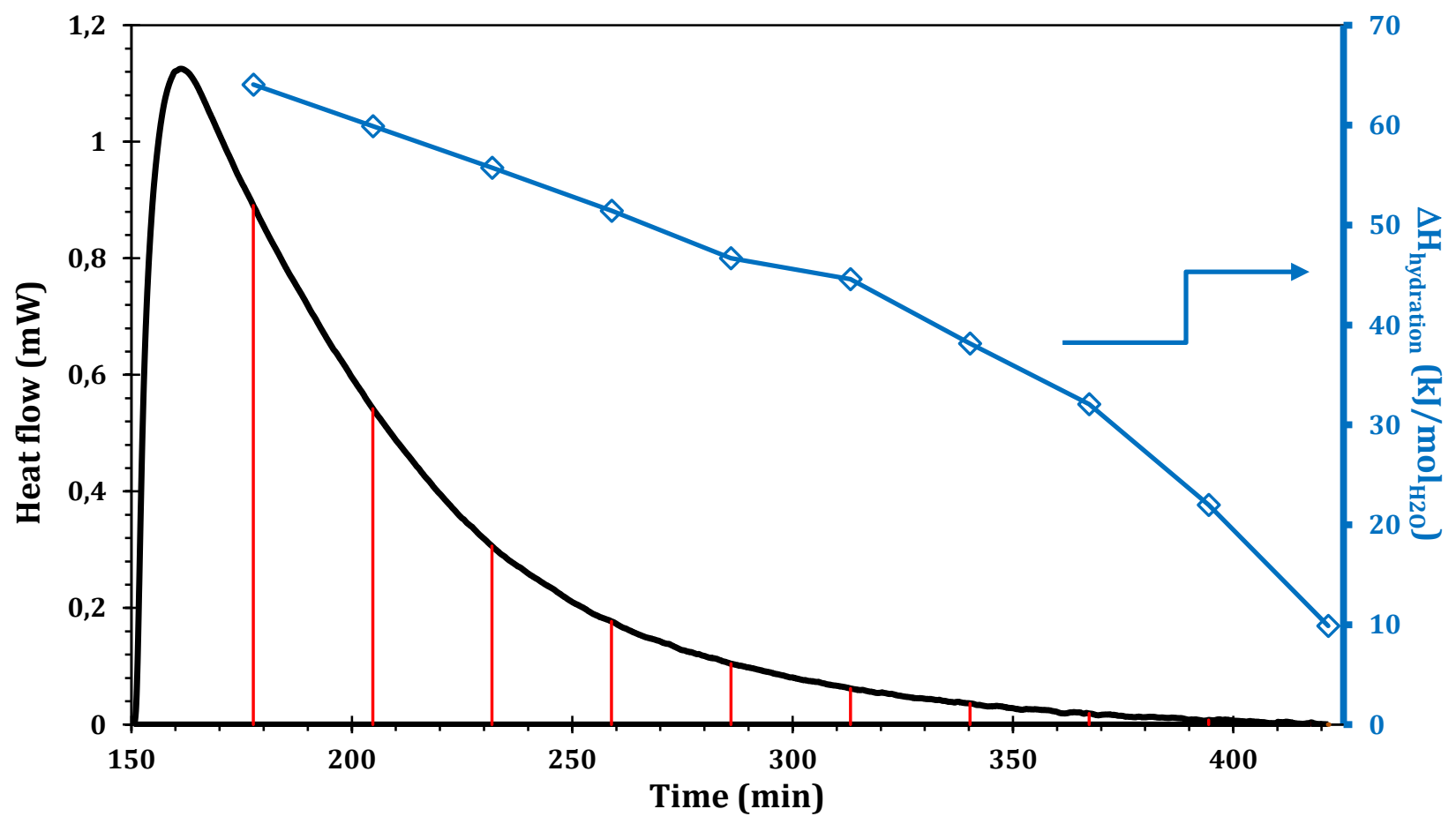

Fig. 10. Hydration enthalpy integration at regular times intervals for the $30-\mathrm{MgSO}_{4} / \mathrm{AC}$ sample (Dehydration at $300{ }^{\circ} \mathrm{C}$ at $5{ }^{\circ} \mathrm{C} / \mathrm{min}$; hydration at $30^{\circ} \mathrm{C}$; $\mathrm{RH}=30 \%$; time: 20 hours. 


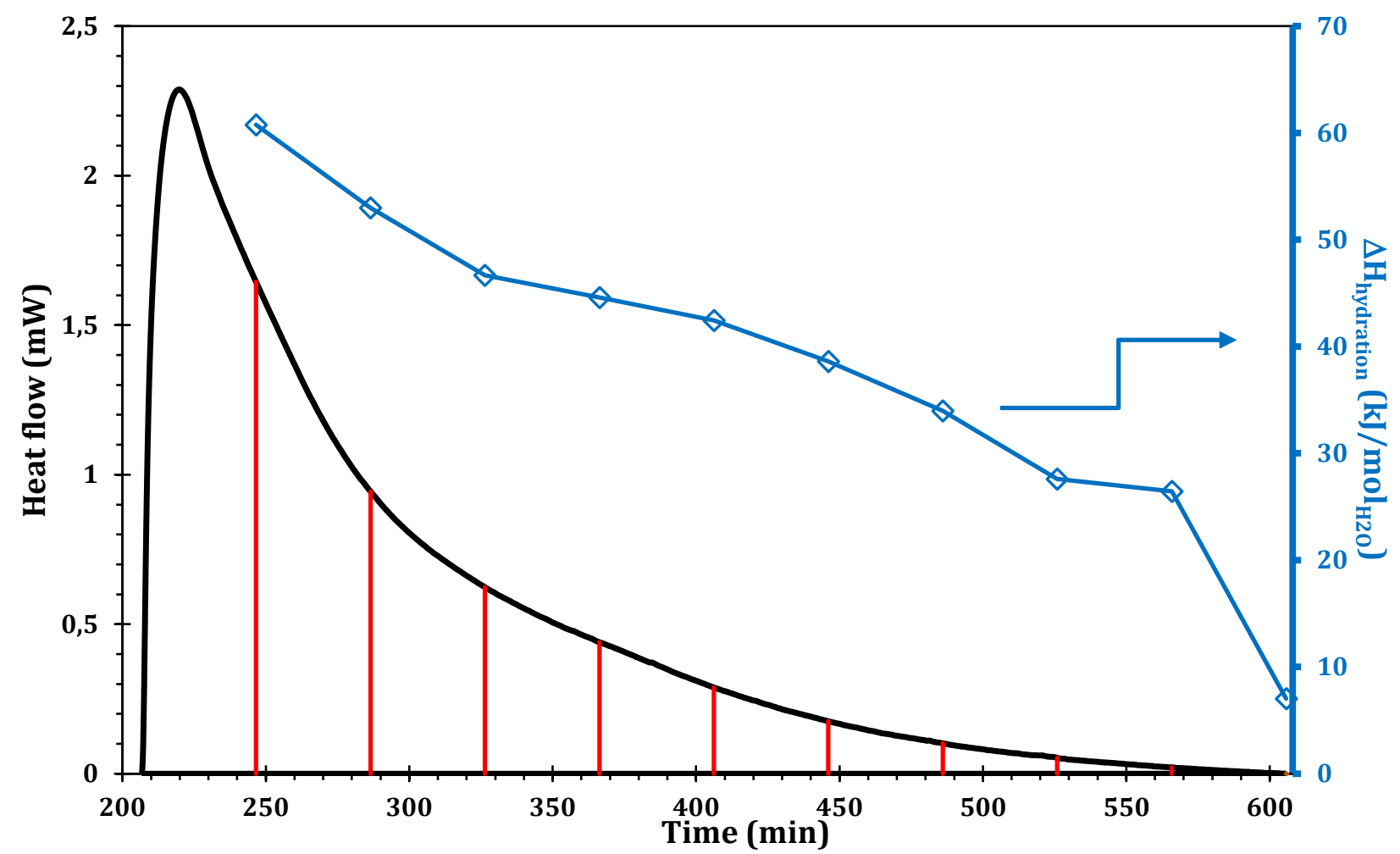

Fig. 11. Hydration enthalpy integration at regular times intervals for the $30-\mathrm{MgSO}_{4} / \mathrm{AC}$ sample (Dehydration at $300{ }^{\circ} \mathrm{C}$ at $5{ }^{\circ} \mathrm{C} / \mathrm{min}$; hydration at $30^{\circ} \mathrm{C}$; $\mathrm{RH}=60 \%$; time: 20 hours)

\section{$\mathrm{MgSO}_{4}$ content (Wt. \%)}

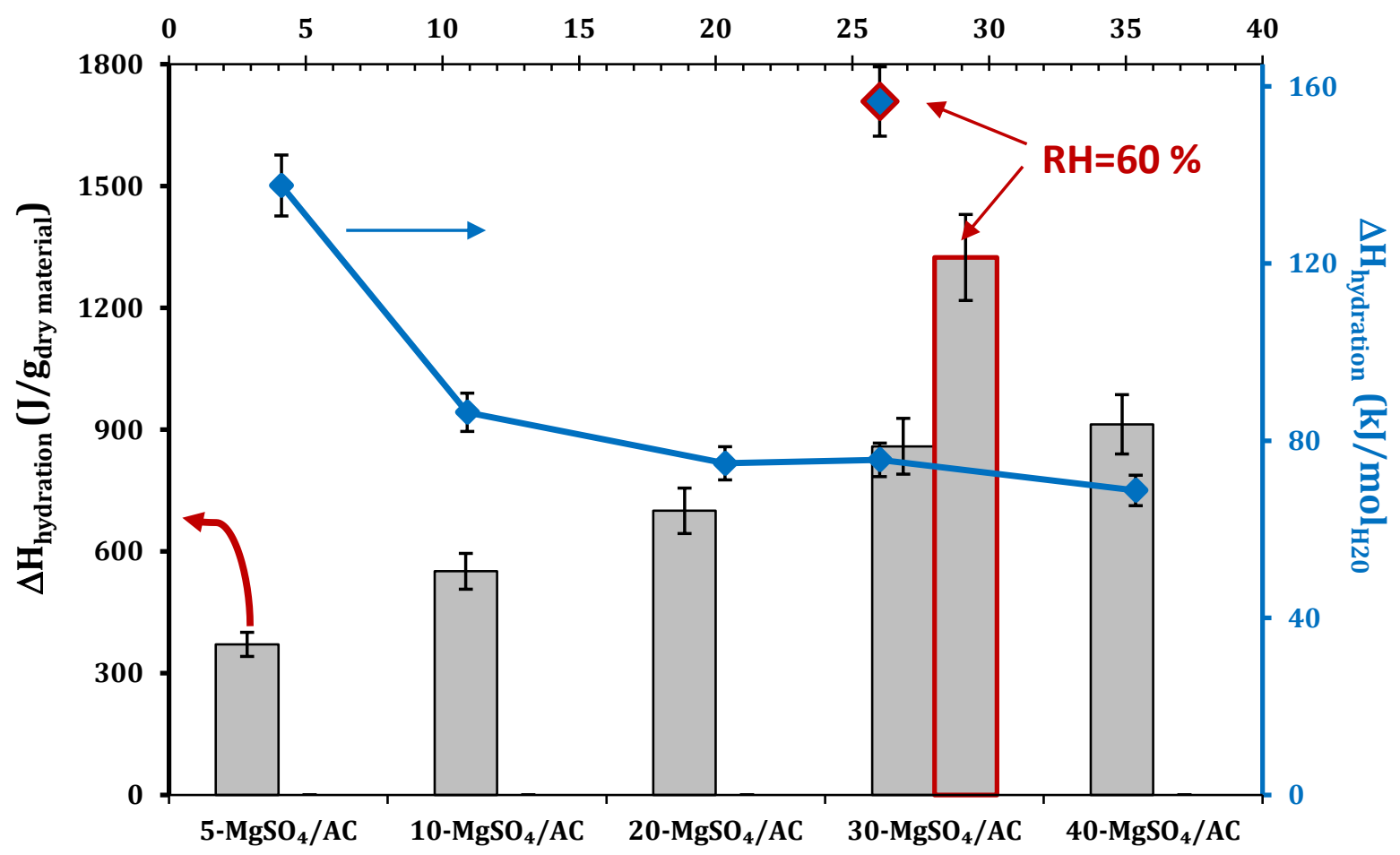

Fig. 12. Hydration enthalpy $(\mathrm{J} / \mathrm{g})$ per gram of prepared composites and mole of water adsorbed $\left(\mathrm{kJ} / \mathrm{mol}_{\mathrm{H} 2 \mathrm{O}}\right)$ for a full hydration $\left(\mathrm{RH}=30 \%\right.$ and $\mathrm{RH}=60 \%$ for $30-\mathrm{MgSO}_{4} / \mathrm{AC}$ sample) 
Grevel et al. [83] measured and enlightened the existence of a linear correlation between the number of water molecules adsorbed and the enthalpy of formation of magnesium sulfate hydrates. Therefore, the higher the degree of hydration of the salt, the greater the energy released. Unfortunately, the impregnation of magnesium sulfate on the AC decreases the pore volume and the surface of the composites, thus decreasing the salt fraction involved in the hydration process (salt trapped in the pores and inaccessible by water molecules, or salt forming thick layers towards which the diffusion of water is restricted). A compromise needs then to be found between the highest quantity of salt that can be deposited on the AC support and the highest heat storage density that can be obtained through the hydration process.

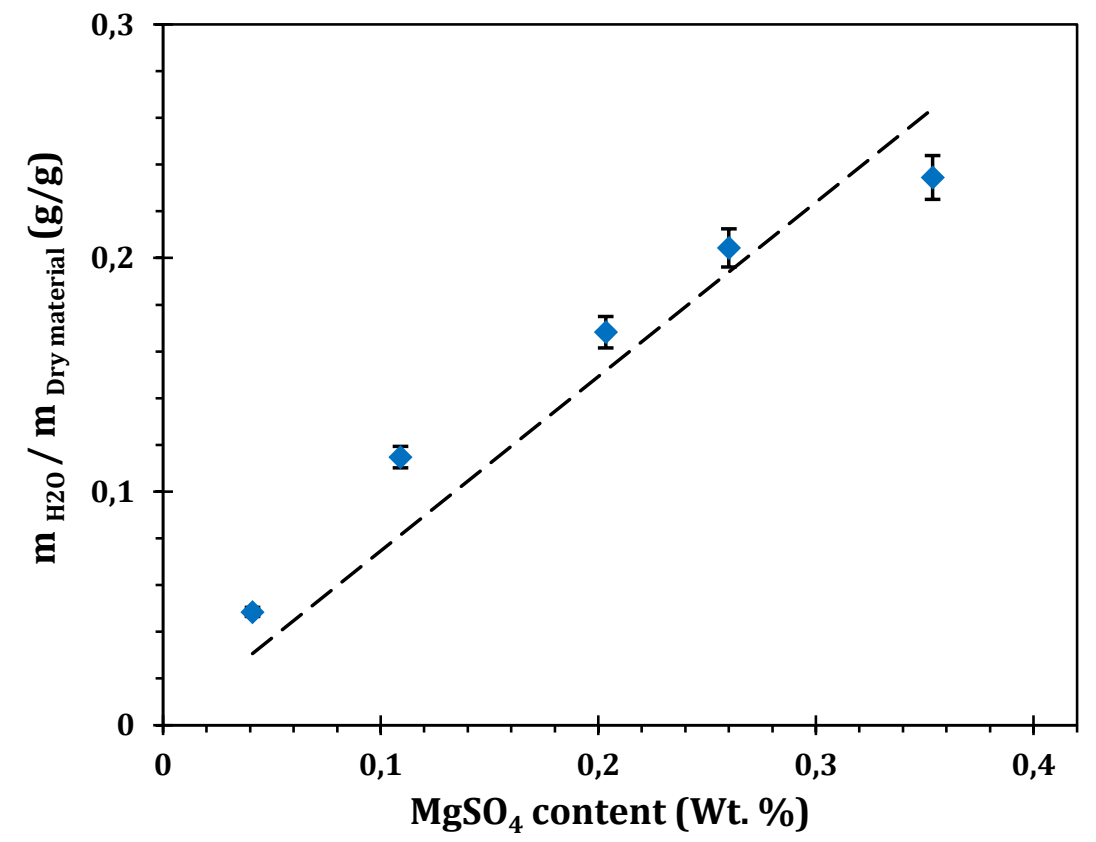

Fig. 13. Effect of $\mathrm{MgSO}_{4}$ salt content on water sorption on the prepared composites (Dehydration at $300{ }^{\circ} \mathrm{C}$ at $5{ }^{\circ} \mathrm{C} / \mathrm{min}$; hydration at $30^{\circ} \mathrm{C}$; $\mathrm{RH}=30 \%$; time: 20 hours)

If the heat release during magnesium sulfate hydration is linearly proportional to its hydration level, as claimed by Grevel et al. [83], it is possible to estimate the necessary amount of magnesium sulfate to deposit in order to optimize the hydration level. Indeed, when the ratio between the quantity of water sorbed per mass unit of composite $\left(\mathrm{m}_{\mathrm{H} 2 \mathrm{O}} / \mathrm{m}_{\mathrm{dry}}\right.$ material $)$ and the 
quantity of magnesium sulfate present on the composite $\left(\mathrm{MgSO}_{4}\right.$ quantity, wt.\%) is below the dotted linear trend curve represented in Fig.13, the optimal quantity of salt to deposit is overtaken. The experimental points in Fig. 13 have been obtained by measuring, using thermogravimetric analysis, the mass difference between the dehydrated and the fully hydrated material. In order to take into account the quantity of water adsorbed exclusively by $\mathrm{MgSO}_{4}$, the measured values were corrected by subtracting the quantity of water adsorbed by the AC support $\left(0.097 \mathrm{~g}_{\mathrm{H} 2 \mathrm{O}} / \mathrm{g}_{\mathrm{dry}} \mathrm{AC}\right)$.

The $\mathrm{MgSO}_{4}$ optimal quantity limit is then located between 26 and 35 wt.\% of magnesium sulfate. This result is confirmed by the heat storage density $\left(\Delta \mathrm{H}_{\text {hydration }}\right)$ measured on the samples and reported in Fig. 12. The hydration enthalpy increases with the quantity of $\mathrm{MgSO}_{4}$ to reach a plateau for a $\mathrm{MgSO}_{4}$ content above $30 \%$ wt $\left(30-\mathrm{MgSO}_{4} / \mathrm{AC}\right.$ and $40-\mathrm{MgSO}_{4} / \mathrm{AC}$ samples). The $30-\mathrm{MgSO}_{4} / \mathrm{AC}$ is also the sample presenting a good salt dispersion with the highest $\mathrm{MgSO}_{4}$ content of the series of composites, as previously shown by XRD and SEM+EDX analysis.

The correlation between the salt hydration level and the hydration enthalpy is also confirmed by the hydration experiment performed on the $30-\mathrm{MgSO}_{4} / \mathrm{AC}$ sample at $\mathrm{RH}=60 \%$. At higher water partial pressure, the water molecule diffusion is improved, and the salt hydration is ameliorated, as previously observed for $\mathrm{MgSO}_{4} /$ zeolite composites [79] and potassium carbonate salt hydrate [96]. The water sorption increased from 0.28 to $0.52 \mathrm{~g}_{\mathrm{H} 20} / \mathrm{g}_{\mathrm{dry}}$ material. The hydration enthalpy of $859 \mathrm{~J} / \mathrm{g}_{\text {dry }}$ material measured at $\mathrm{RH}=30 \%$ increases to $1324 \mathrm{~J} / \mathrm{g}_{\text {dry }}$ material at RH=60\%. Such values are very promising when compared to those obtained for wellperforming storage materials reported in the literature $[68,69,79]$.

\subsection{Hydration/dehydration cycles}


In order to evaluate the stability of the composites after several hydration/dehydration cycles, several consecutive experiments have been performed on the $30-\mathrm{MgSO}_{4} / \mathrm{AC}$ sample, alternating dehydration steps at $150^{\circ} \mathrm{C}$ and short hydration steps of 4 hours' duration at $\mathrm{RH}=30$ $\%$. The measures of hydration enthalpies are reported in Fig. 14. For the first 8 cycles, no decreasing trend was detected in the heat storage capacity of the material.

Moreover, with the aim to verifying if any modification of the salt deposit on the AC surface took place, SEM observations were performed after cycling (Fig. 15).

The magnesium sulfate salt reorganizes on the AC surface during the successive hydration/dehydration steps. The very well dispersed salt film, present on the fresh composite (Fig. 4), forms, after 8 cycles, salt filaments homogeneously dispersed on the surface (Fig.15). Despite this structural change, the hydration enthalpy remains unchanged. This modification of the structure does not evidently affect the water diffusion, and the salt hydration remains efficient. On the AC support, the crystallization and the formation of a thick salt crust are absent or, in any case, not pronounced enough to decrease the diffusion of water molecules.

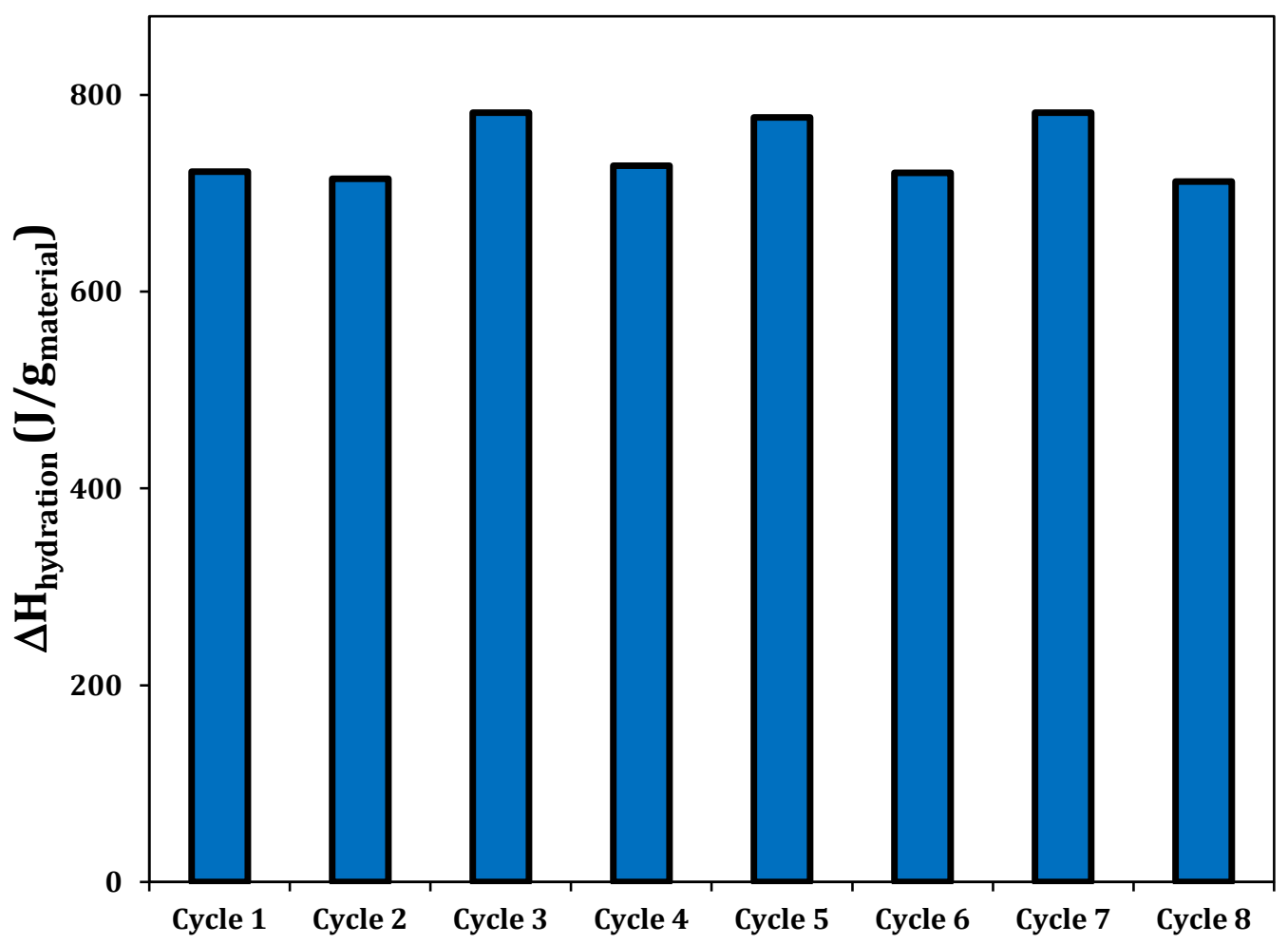


Fig. 14. Heat of hydration and mass changes to study stability over cycles for 30-MgSO $4 / A C$ sample (Dehydration at $150{ }^{\circ} \mathrm{C}$ at $5{ }^{\circ} \mathrm{C} / \mathrm{min}$; hydration at $30^{\circ} \mathrm{C}$; $\mathrm{RH}=30 \%$; time: 20 hours)

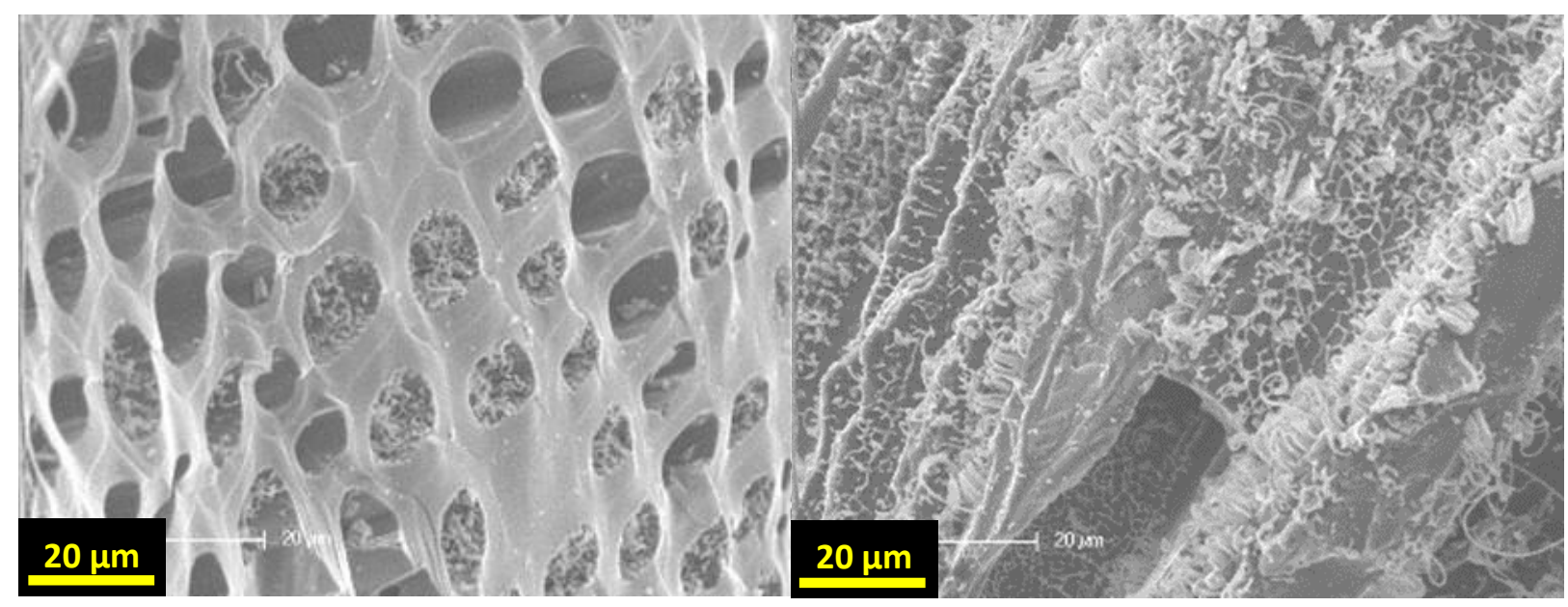

Fig. 15. Salt crystallization after the first cycle on $30-\mathrm{MgSO}_{4} / \mathrm{AC}$. (Dehydration at $300{ }^{\circ} \mathrm{C}$ at 5 ${ }^{\circ} \mathrm{C} / \mathrm{min}$; hydration at $30^{\circ} \mathrm{C}$; $\mathrm{RH}=30 \%$; time: 20 hours)

\subsection{Operation scenarios of a thermochemical heat storage system for domestic use}

The aim of the following numerical study is to develop a numerical tool able to simulate different operating scenarios. The heat storage and release were simulated for ambient and domestic water heating in a passive house. The $30-\mathrm{MgSO}_{4} / \mathrm{AC}$ composite was the storage material selected for simulating the system.

In order to provide a simple, flexible, and effective simulation tool, the selected geometry for the storage reactor was cylindrical. An asymmetric 1D unsteady model was then developed; it included mass, momentum, and energy balances in the material and in the fluid (air). In the model, the fluid (moist air from controlled ventilation) enters the reactor, passes through the material, and transports the heat to the exit of the reactor. The air acts, at the same time as a water and heat carrier.

The modelling program simulates the thermal behavior of a tubular reactor operating under laminar flow. The fluid (moist air) is assumed to be perfectly mixed at the reactor inlet. The 
flow field in the reactor is described by the unsteady mass, energy, and water concentration balances [97]. The equations used in the model are presented as follows.

The continuity equation is:

$$
\left(\frac{\partial \rho_{a}}{\partial T_{a}}\right)\left(\frac{\partial T_{a}}{\partial t}\right)+\frac{d\left(\rho_{a} u\right)}{d z}=0
$$

Where $\rho_{a}, T_{a}$ are respectively the air density and temperature, $u$ the air velocity in the reactor, $t$ the time, and $z$ the reactor axis coordinate.

The energy balance in the material is expressed by the following equation:

$$
\left[\rho_{m} C p_{m} \frac{\partial T_{m}}{\partial t}-\lambda_{m} \frac{\partial^{2} T_{m}}{\partial z^{2}}\right] S d z=\Delta_{r} H\left(m_{w}\right) \frac{\partial m_{w}}{\partial t}+h S\left(T_{a}-T_{m}\right)
$$

Where $\rho_{m}, \mathrm{Cp}, \lambda_{m}, T_{m}$ are the density, the specific heat, the thermal conductivity, and the temperature of the material, respectively. $S$ is the reactor section, $m_{w}$ is the mass of water in the material, $h$ is the heat exchange coefficient between air and the material and $\Delta_{r} H\left(m_{w}\right)$ is the reaction heat.

A linear law was applied to take into account the kinetics of adsorption in the material. The amount of adsorbed water during $\mathrm{dt}$ in the volume $\mathrm{Sdz}$ is:

$$
\frac{\partial m_{w}}{\partial t}=X_{w} \frac{m_{w}(\infty)-m_{w}(t, z)}{m_{w}(\infty)} \rho_{a} u S
$$

Where $X_{w}$ is the water content in the material and $m_{w}(\infty)$ the mass of water adsorbed in the material at equilibrium.

The energy balance in air is expressed as:

$$
\left[\rho_{a} C p_{a}\left(\frac{\partial T_{a}}{\partial t}+u \frac{\partial T_{a}}{\partial z}\right)-\lambda_{a} \frac{d^{2} T_{a}}{d z^{2}}\right] S d z=-h S\left(T_{a}-T_{m}\right)
$$

Where $C p_{a}$ and $\lambda_{a}$ are the specific heat and the thermal conductivity of air, respectively. 
And the water mass balance in the air as:

$$
\rho_{a} S d z \frac{\partial X_{w}}{\partial t}=-\frac{\partial m_{w}}{\partial t}
$$

The heat released from the storage material during hydration was deduced from the experimental results obtained by differential scanning calorimetry coupled to thermogravimetry (thermal flux and mass vs. time). For this purpose, $\Delta_{r} H\left(m_{w}\right)$ was calculated by numerical integration for various amounts of adsorbed water. Fig. 16 shows the heat released from the material during hydration with air at $30{ }^{\circ} \mathrm{C}$ (at $\left.30 \% \mathrm{RH}\right)$, as a function of the mass fraction of water in the material.

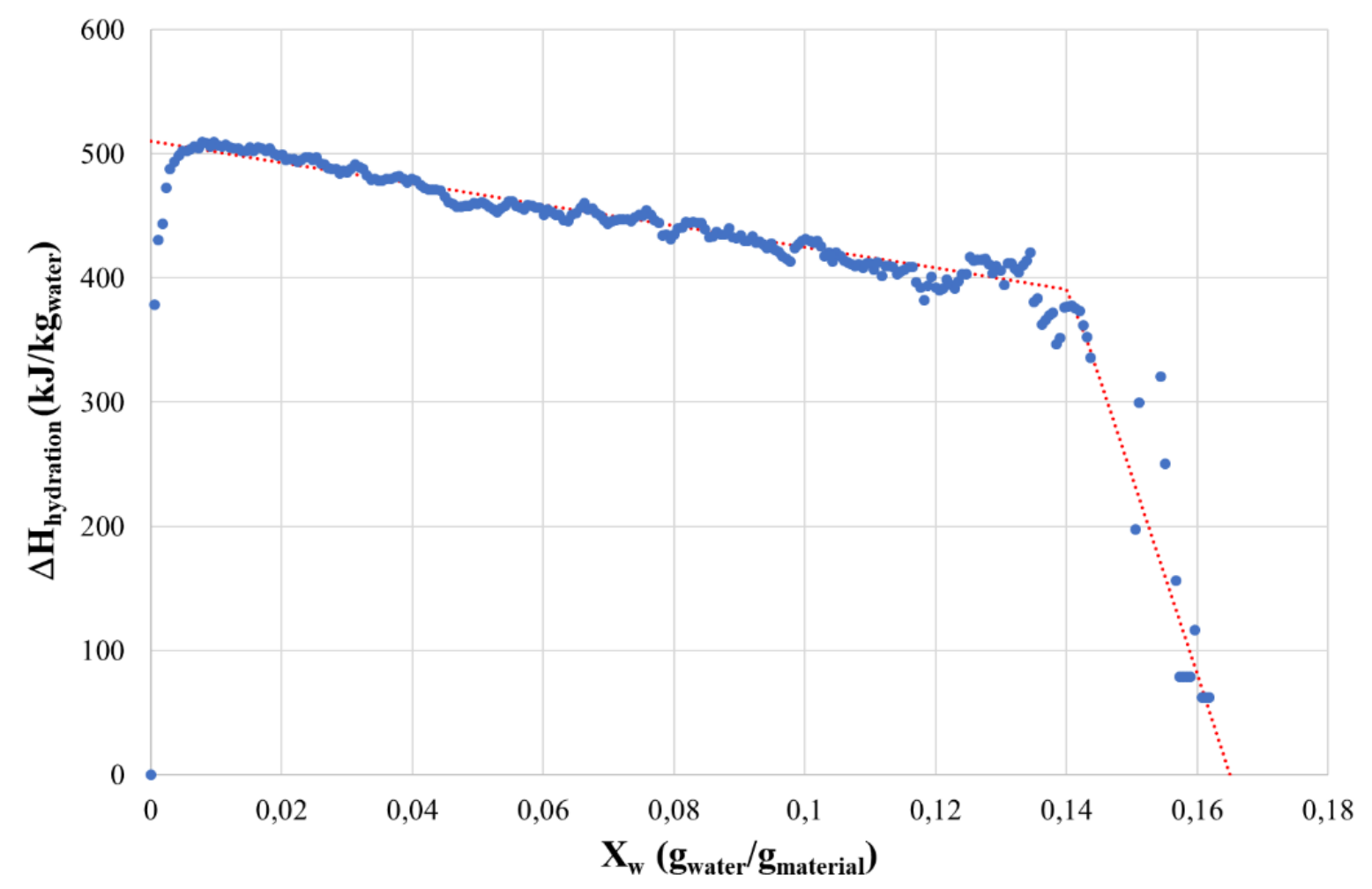

Fig. 16. Heat release during water adsorption versus mass fraction of water sorbed. Test performed at $\mathrm{T}=30^{\circ} \mathrm{C}$ and $30 \% \mathrm{RH}$.

Then, a linear approximation was performed to obtain:

$\frac{m_{w}}{\rho_{m} S d z} \leq 0.14 \quad \Delta_{r} H=f\left(m_{w}\right)=510-850 \frac{m_{w}}{\rho_{m} S d z}(\mathrm{~kJ} / \mathrm{kg}$ of sorbed water $)$ 
$0.14<\frac{m_{w}}{\rho_{m} S d z} \leq 0.165 \quad \Delta_{r} H=f\left(m_{w}\right)=2640-16000 \frac{m_{w}}{\rho_{m} S d z}(\mathrm{~kJ} / \mathrm{kg}$ of sorbed water $)$

The boundary conditions were: $\mathrm{T}_{\mathrm{a}}(\mathrm{z}=0)=\mathrm{T}_{0}, \mathrm{~T}_{\mathrm{m}}(\mathrm{z}, \mathrm{t}=0)=\mathrm{T}_{0}, u(t, z=0)=\frac{\text { Qinlet }}{\rho_{a} S}$, $\mathrm{X}_{\mathrm{w}}(\mathrm{z}=0, \mathrm{t})=\mathrm{X}_{0}$

Fig. 17 is a schematic representation of the two studied scenarios. The first scenario (Fig. 17a) is based on the use of the storage system for heating the house (during winter for example). The second (Fig. 17b) is oriented on the use of the storage system for supplying a complement of energy for producing hot sanitary water. This scenario corresponds to the periods in which the demand for central heating is absent or low. In the first case, the storage unit is an additional system intended to provide energy for special situations (severe weather conditions). The second is the use of the stored energy for heating domestic water during short periods in which the solar irradiation is limited (mostly in summer).
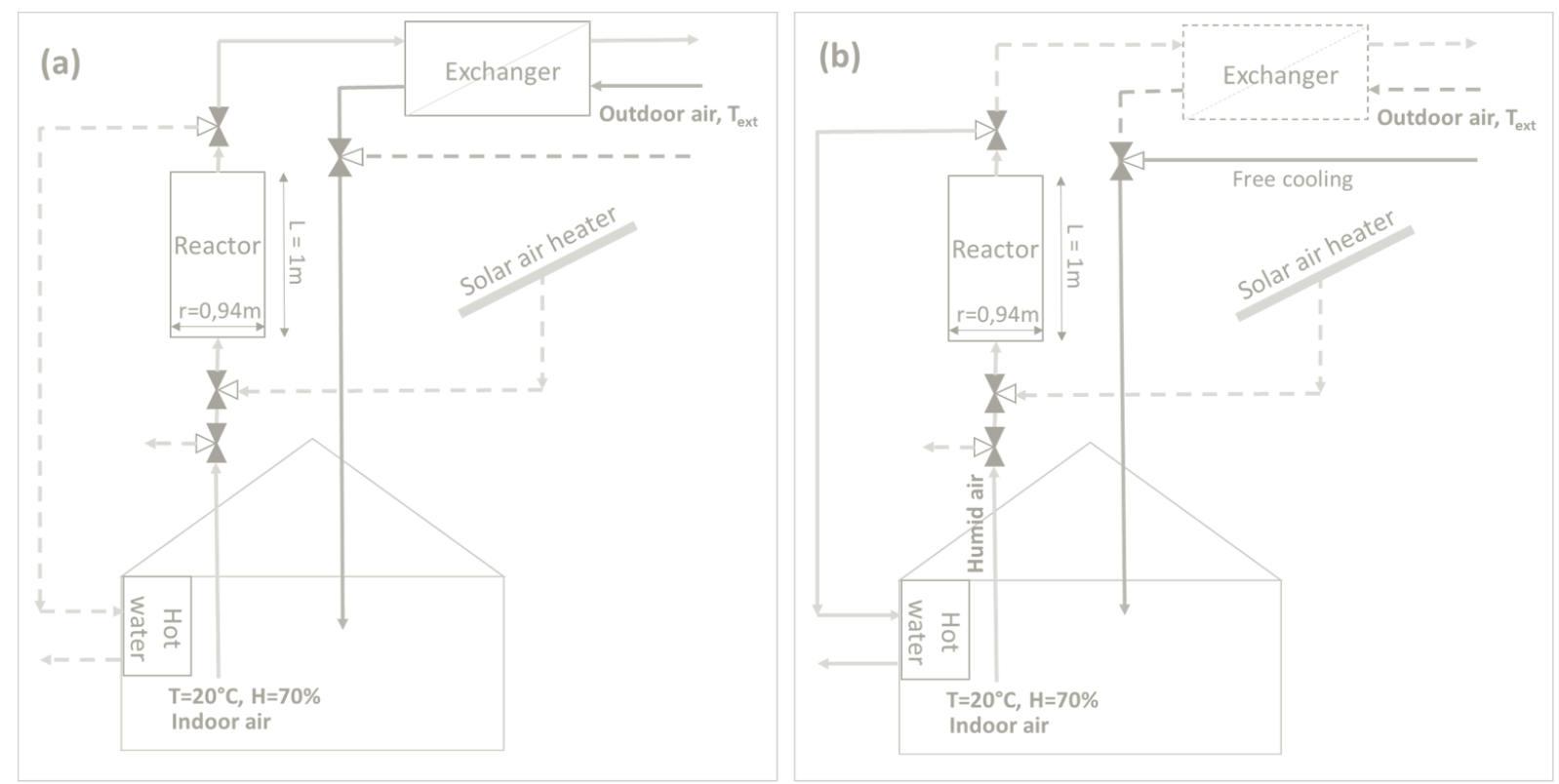

Fig. 17. Schemes of the two studied scenarios. House heating (a) and sanitary hot water production (b)

For the two simulations, the material is supposed to be firstly completely dehydrated by the hot and dry air by means of solar heaters. 
For the first scenario (heating), the reactor permits production of $361 \mathrm{kWh}$ of thermal energy with an air temperature of $65.6{ }^{\circ} \mathrm{C}$ at the reactor outlet. If the inlet air is maximized, the system can deliver a heat power of about $3.6 \mathrm{~kW}$ for more than 4 days. This value is in agreement with the required heat input for such type building (passive house, $\sim 15 \mathrm{kWh} /\left(\mathrm{m}^{2} \cdot\right.$ year) $)$ [98].

The heat demand management is linearly controlled by the fraction of indoor air directly send into the reactor $\left(0<\mathrm{Q}_{\text {inlet }}<250 \mathrm{~m}^{3} / \mathrm{h}\right.$, being $250 \mathrm{~m}^{3} / \mathrm{h}$ the maximum flow of the recirculating system).

In the second scenario, the heat storage system is used to supply a complement of energy to warm-up the sanitary water, when the energy given by the solar heater is not sufficient (i.g. cloudy days). For this purpose, the entire flow of air entering/exiting from the reactor $\left(\mathrm{Q}_{\text {inlet }}=\right.$ $250 \mathrm{~m}^{3} / \mathrm{h}$ ) is sent to the "hot water" system (see Fig. $17 \mathrm{~b}$ ). The heating power is approximately $3.5 \mathrm{~kW}$, which is sufficient to warm-up for 14 times $300 \mathrm{~L}$ of water from 15 to approximately $60{ }^{\circ} \mathrm{C}$ in less than 8 hours (assuming an effective efficiency of $60 \%$ ), with no need to recharge the system [99].

\section{Conclusion}

Heat storage by sorption has been investigated in this study by several $\mathrm{MgSO}_{4} / \mathrm{AC}$ composites. The results of composite characterization revealed a homogeneous dispersion of magnesium sulfate in composites prepared by incipient wetness impregnation.. The hydration enthalpy showed an increase by increasing the $\mathrm{MgSO}_{4}$ content on $\mathrm{AC}$ to reach a plateau for a $\mathrm{MgSO}_{4}$ content above $30 \% \mathrm{wt}$ (30- $\mathrm{MgSO}_{4} / \mathrm{AC}$ and $40-\mathrm{MgSO}_{4} / \mathrm{AC}$ samples). The correlation between the salt hydration level and the hydration enthalpy was also confirmed by the hydration experiment performed on the $30-\mathrm{MgSO}_{4} / \mathrm{AC}$ sample at $\mathrm{RH}=60 \%$. At higher water partial pressure, the water molecule diffusion was improved, and the salt hydration was ameliorated. The hydration enthalpy of $30-\mathrm{MgSO}_{4} / \mathrm{AC}$ at $\mathrm{RH}=30 \%$ was increased from $859 \mathrm{~J} / \mathrm{g}_{\text {dry }}$ material to $1324 \mathrm{~J} / \mathrm{g}_{\text {dry material }}$ at $\mathrm{RH}=60 \%$. The stability of $30-\mathrm{MgSO}_{4} / \mathrm{AC}$ sample was found to be nearly stable after 8 cycles of hydration/dehydration. Moreover, two different scenarios for heating a house and for the production of sanitary hot water were simulated for the $30-\mathrm{MgSO}_{4} / \mathrm{AC}$ ) 
composite. In addition to the need to test the stability of the material under a higher number of hydration/dehydration cycles, in both scenarios, the possibility to implement the synthesized material in a domestic heat storage system was confirmed. New research is ongoing related to the effect of binary salt impregnation and the effect of different methods of composites preparation on heat storage performance.

Funding: - Région Grand Est for providing funding for the acquisition of the TG-DSC equipment within the "STOCKFATAL project and for the contribution to Mr. Minh Hoang Nguyen's thesis grant.

- Carnot MICA for funding part of this study in the frame of the STOCKENER project.

\section{Acknowledgements}

The authors would like to thank the Carnot Institutes MICA(France) for supporting a part of this study within the STOCKENER; Region Grand Est (France) for providing funding for the acquisition of the TG-DSC equipment, in the frame of STOCKFATAL project, and financing a part of the PhD-grant of Mr Minh Hoang Nguyen.

All physico-chemical characterizations were performed on the IS2M technical platforms. The authors are very grateful to L. Michelin (XRF) and L. Josien (SEM+EDX) for their contribution.

\section{List of References}

[1] Adeniyi AG, Otoikhian KS, Ighalo JO. Steam Reforming of Biomass Pyrolysis Oil: A Review. Int J Chem React Eng 2019;17. https://doi.org/10.1515/ijcre-2018-0328.

[2] Hosseini S, Moradi GR, Bahrami K. Acidic Functionalized Nanobohemite: An Active Catalyst for Methyl Ester Production. Int J Chem React Eng 2019;17. 
https://doi.org/10.1515/ijcre-2018-0283.

[3] Roschat W, Siritanon T, Kaewpuang T, Yoosuk B, Promarak V. Economical and green biodiesel production process using river snail shells-derived heterogeneous catalyst and co-solvent method. Bioresour Technol 2016;209:343-50.

https://doi.org/10.1016/j.biortech.2016.03.038.

[4] Yoro KO, Daramola MO. CO2 emission sources, greenhouse gases, and the global warming effect. Adv. Carbon Capture, Elsevier; 2020, p. 3-28. https://doi.org/10.1016/B978-0-12-819657-1.00001-3.

[5] Fasihi M, Efimova O, Breyer C. Techno-economic assessment of CO2 direct air capture plants. J Clean Prod 2019;224:957-80. https://doi.org/10.1016/j.jclepro.2019.03.086.

[6] Janssens-Maenhout G, Crippa M, Guizzardi D, Muntean M, Schaaf E, Dentener F, et al. EDGAR v4.3.2 Global Atlas of the three major greenhouse gas emissions for the period 1970-2012. Earth Syst Sci Data 2019;11:959-1002. https://doi.org/10.5194/essd-11-959-2019.

[7] Wang C, Li X, Min Q, Wang W, Sardans J, Zeng C, et al. Responses of greenhouse-gas emissions to land-use change from rice to jasmine production in subtropical China. Atmos Environ 2019;201:391-401. https://doi.org/10.1016/j.atmosenv.2018.12.032.

[8] Pettinari C, Tombesi A. Metal-organic frameworks for carbon dioxide capture. MRS Energy Sustain 2020;7:35. https://doi.org/10.1557/mre.2020.30.

[9] Sandesh S, Kristachar PKR, Manjunathan P, Halgeri AB, Shanbhag G V. Synthesis of biodiesel and acetins by transesterification reactions using novel $\mathrm{CaSn}(\mathrm{OH}) 6$ heterogeneous base catalyst. Appl Catal A Gen 2016;523:1-11. https://doi.org/10.1016/j.apcata.2016.05.006.

[10] Peng X, Root TW, Maravelias CT. Storing solar energy with chemistry: the role of 
thermochemical storage in concentrating solar power. Green Chem 2017;19:2427-38. https://doi.org/10.1039/C7GC00023E.

[11] Li G. Organic Rankine cycle performance evaluation and thermoeconomic assessment with various applications part I: Energy and exergy performance evaluation. Renew Sustain Energy Rev 2016;53:477-99. https://doi.org/10.1016/j.rser.2015.08.066.

[12] Li G, Zheng X. Thermal energy storage system integration forms for a sustainable future. Renew Sustain Energy Rev 2016;62:736-57. https://doi.org/10.1016/j.rser.2016.04.076.

[13] Li G. Energy and exergy performance assessments for latent heat thermal energy storage systems. Renew Sustain Energy Rev 2015;51:926-54. https://doi.org/10.1016/j.rser.2015.06.052.

[14] Li G, Hwang Y, Radermacher R, Chun H-H. Review of cold storage materials for subzero applications. Energy 2013;51:1-17. https://doi.org/10.1016/j.energy.2012.12.002.

[15] Li G, Hwang Y, Radermacher R. Review of cold storage materials for air conditioning application. Int J Refrig 2012;35:2053-77. https://doi.org/10.1016/j.ijrefrig.2012.06.003.

[16] Li G, Hwang Y. Energy Storage Systems for Buildings. Handb. Integr. Sustain. Build. Equip. Syst. Vol. I Energy Syst., ASME Press; 2017, p. 347-420. https://doi.org/10.1115/1.861271_ch8.

[17] Chen X, Jin X, Zhang Z, Song D, Ling X, Wang Y, et al. Experimental investigation of $\mathrm{CaCO} 3 / \mathrm{CaO}$ in a spiral coil reactor for thermochemical energy storage. Chem Eng J 2022;428:131971. https://doi.org/10.1016/j.cej.2021.131971.

[18] Aydin D, Casey SP, Riffat S. The latest advancements on thermochemical heat storage systems. Renew Sustain Energy Rev 2015;41:356-67. 
https://doi.org/10.1016/j.rser.2014.08.054.

[19] Cabeza LF, Solé A, Barreneche C. Review on sorption materials and technologies for heat pumps and thermal energy storage. Renew Energy 2017;110:3-39. https://doi.org/10.1016/j.renene.2016.09.059.

[20] N'Tsoukpoe KE, Liu H, Le Pierrès N, Luo L. A review on long-term sorption solar energy storage. Renew Sustain Energy Rev 2009;13:2385-96. https://doi.org/10.1016/j.rser.2009.05.008.

[21] Kausar A, Sher F, Hazafa A, Javed A, Sillanpää M, Iqbal M. Biocomposite of sodiumalginate with acidified clay for wastewater treatment: Kinetic, equilibrium and thermodynamic studies. Int J Biol Macromol 2020;161:1272-85. https://doi.org/10.1016/j.ijbiomac.2020.05.266.

[22] Rashid T, Iqbal D, Hazafa A, Hussain S, Sher F, Sher F. Formulation of zeolite supported nano-metallic catalyst and applications in textile effluent treatment. J Environ Chem Eng 2020;8:104023. https://doi.org/10.1016/j.jece.2020.104023.

[23] Sehar S, Sher F, Zhang S, Khalid U, Sulejmanović J, Lima EC. Thermodynamic and kinetic study of synthesised graphene oxide-CuO nanocomposites: A way forward to fuel additive and photocatalytic potentials. J Mol Liq 2020;313:113494. https://doi.org/10.1016/j.molliq.2020.113494.

[24] Rasheed T, Shafi S, Bilal M, Hussain T, Sher F, Rizwan K. Surfactants-based remediation as an effective approach for removal of environmental pollutants-A review. J Mol Liq 2020;318:113960. https://doi.org/10.1016/j.molliq.2020.113960.

[25] Rasheed T, Ahmad N, Nawaz S, Sher F. Photocatalytic and adsorptive remediation of hazardous environmental pollutants by hybrid nanocomposites. Case Stud Chem Environ Eng 2020;2:100037. https://doi.org/10.1016/j.cscee.2020.100037.

[26] Rasheed T, Hassan AA, Kausar F, Sher F, Bilal M, Iqbal HMN. Carbon nanotubes 
assisted analytical detection - Sensing/delivery cues for environmental and biomedical monitoring. TrAC Trends Anal Chem 2020;132:116066.

https://doi.org/10.1016/j.trac.2020.116066.

[27] Li G, Qian S, Lee H, Hwang Y, Radermacher R. Experimental investigation of energy and exergy performance of short term adsorption heat storage for residential application. Energy 2014;65:675-91. https://doi.org/10.1016/j.energy.2013.12.017.

[28] Li G, Hwang Y, Radermacher R. Experimental investigation on energy and exergy performance of adsorption cold storage for space cooling application. Int J Refrig 2014;44:23-35. https://doi.org/10.1016/j.ijrefrig.2014.05.013.

[29] Tatsidjodoung P, Le Pierrès N, Luo L. A review of potential materials for thermal energy storage in building applications. Renew Sustain Energy Rev 2013;18:327-49. https://doi.org/10.1016/j.rser.2012.10.025.

[30] Dicaire D, Tezel FH. Regeneration and efficiency characterization of hybrid adsorbent for thermal energy storage of excess and solar heat. Renew Energy 2011;36:986-92. https://doi.org/10.1016/j.renene.2010.08.031.

[31] Yan T, Wang RZ, Li TX, Wang LW, Fred IT. A review of promising candidate reactions for chemical heat storage. Renew Sustain Energy Rev 2015;43:13-31. https://doi.org/10.1016/j.rser.2014.11.015.

[32] Deshmukh H, Maiya MP, Srinivasa Murthy S. Study of sorption based energy storage system with silica gel for heating application. Appl Therm Eng 2017;111:1640-6. https://doi.org/10.1016/j.applthermaleng.2016.07.069.

[33] Lim K, Che J, Lee J. Experimental study on adsorption characteristics of a water and silica-gel based thermal energy storage (TES) system. Appl Therm Eng 2017;110:808. https://doi.org/10.1016/j.applthermaleng.2016.08.098.

[34] Henninger SK, Ernst S-J, Gordeeva L, Bendix P, Fröhlich D, Grekova AD, et al. New 
materials for adsorption heat transformation and storage. Renew Energy 2017;110:5968. https://doi.org/10.1016/j.renene.2016.08.041.

[35] Rustam L, Jeremias F, Henninger SK, Wolff T, Munz GM. Tuning of adsorbent properties - oxidative hydrophilization of activated carbon monoliths for heat storage applications. Energy Build 2019;196:206-13. https://doi.org/10.1016/j.enbuild.2019.05.024.

[36] Permyakova A, Skrylnyk O, Courbon E, Affram M, Wang S, Lee U-H, et al. Synthesis Optimization, Shaping, and Heat Reallocation Evaluation of the Hydrophilic MetalOrganic Framework MIL-160(Al). ChemSusChem 2017;10:1419-26. https://doi.org/10.1002/cssc.201700164.

[37] Elsayed A, Elsayed E, AL-Dadah R, Mahmoud S, Elshaer A, Kaialy W. Thermal energy storage using metal-organic framework materials. Appl Energy 2017;186:509_ 19. https://doi.org/10.1016/j.apenergy.2016.03.113.

[38] Bon V. Metal-organic frameworks for energy-related applications. Curr Opin Green Sustain Chem 2017;4:44-9. https://doi.org/10.1016/j.cogsc.2017.02.005.

[39] Köll R, van Helden W, Engel G, Wagner W, Dang B, Jänchen J, et al. An experimental investigation of a realistic-scale seasonal solar adsorption storage system for buildings. Sol Energy 2017;155:388-97. https://doi.org/10.1016/j.solener.2017.06.043.

[40] Whiting GT, Grondin D, Stosic D, Bennici S, Auroux A. Zeolite-MgCl2 composites as potential long-term heat storage materials: Influence of zeolite properties on heats of water sorption. Sol Energy Mater Sol Cells 2014;128:289-95. https://doi.org/10.1016/j.solmat.2014.05.016.

[41] Whiting G, Grondin D, Bennici S, Auroux A. Heats of water sorption studies on zeolite-MgSO4 composites as potential thermochemical heat storage materials. Sol Energy Mater Sol Cells 2013;112:112-9. https://doi.org/10.1016/j.solmat.2013.01.020. 
[42] D'Ans P, Courbon E, Frère M, Descy G, Segato T, Degrez M. Severe corrosion of steel and copper by strontium bromide in thermochemical heat storage reactors. Corros Sci 2018;138:275-83. https://doi.org/10.1016/j.corsci.2018.04.020.

[43] Solé A, Miró L, Barreneche C, Martorell I, Cabeza LF. Corrosion of metals and salt hydrates used for thermochemical energy storage. Renew Energy 2015;75:519-23. https://doi.org/10.1016/j.renene.2014.09.059.

[44] Zbair M, Bennici S. Survey Summary on Salts Hydrates and Composites Used in Thermochemical Sorption Heat Storage: A Review. Energies 2021;14:3105. https://doi.org/10.3390/en14113105.

[45] Gordeeva LG, Aristov YI. Composites ‘salt inside porous matrix' for adsorption heat transformation: a current state-of-the-art and new trends. Int J Low-Carbon Technol 2012;7:288-302. https://doi.org/10.1093/ijlct/cts050.

[46] Yan TS, Li TX, Xu JX, Wang RZ. Water sorption properties, diffusion and kinetics of zeolite $\mathrm{NaX}$ modified by ion-exchange and salt impregnation. Int J Heat Mass Transf 2019;139:990-9. https://doi.org/10.1016/j.ijheatmasstransfer.2019.05.080.

[47] Aristov YI, Kovalevskaya YA, Tokarev MM, Paukov IE. Low temperature heat capacity of the system "silica gel-calcium chloride-water." J Therm Anal Calorim 2011;103:773-8. https://doi.org/10.1007/s10973-010-0981-8.

[48] Tokarev M, Gordeeva L, Romannikov V, Glaznev I, Aristov Y. New composite sorbent $\mathrm{CaCl} 2$ in mesopores for sorption cooling/heating. Int J Therm Sci 2002;41:470-4. https://doi.org/10.1016/S1290-0729(02)01339-X.

[49] Courbon E, D’Ans P, Permyakova A, Skrylnyk O, Steunou N, Degrez M, et al. A new composite sorbent based on $\mathrm{SrBr} 2$ and silica gel for solar energy storage application with high energy storage density and stability. Appl Energy 2017;190:1184-94. https://doi.org/10.1016/j.apenergy.2017.01.041. 
[50] Gordeeva L., Restuccia G, Freni A, Aristov Y. Water sorption on composites "LiBr in a porous carbon.” Fuel Process Technol 2002;79:225-31. https://doi.org/10.1016/S0378-3820(02)00186-8.

[51] Shi W, Zhu Y, Shen C, Shi J, Xu G, Xiao X, et al. Water sorption properties of functionalized MIL-101(Cr)-X (X=-NH2, $-\mathrm{SO} 3 \mathrm{H}, \mathrm{H},-\mathrm{CH} 3,-\mathrm{F})$ based composites as thermochemical heat storage materials. Microporous Mesoporous Mater 2019;285:129-36. https://doi.org/10.1016/j.micromeso.2019.05.003.

[52] D’Ans P, Courbon E, Permyakova A, Nouar F, Simonnet-Jégat C, Bourdreux F, et al. A new strontium bromide MOF composite with improved performance for solar energy storage application. J Energy Storage 2019;25:100881. https://doi.org/10.1016/j.est.2019.100881.

[53] Grekova A, Gordeeva L, Aristov Y. Composite sorbents "Li/Ca halogenides inside Multi-wall Carbon Nano-tubes” for Thermal Energy Storage. Sol Energy Mater Sol Cells 2016;155:176-83. https://doi.org/10.1016/j.solmat.2016.06.006.

[54] Aristov YI, Restuccia G, Tokarev MM, Buerger HD, Freni A. Selective water sorbents for multiple applications. 11. $\mathrm{CaCl} 2$ confined to expanded vermiculite. React Kinet Catal Lett 2000;71:377-84. https://doi.org/10.1023/A:1010351815698.

[55] Mahon D, Henshall P, Claudio G, Eames PC. Feasibility study of MgSO4 + zeolite based composite thermochemical energy stores charged by vacuum flat plate solar thermal collectors for seasonal thermal energy storage. Renew Energy 2020;145:1799_ 807. https://doi.org/10.1016/j.renene.2019.05.135.

[56] Aristov YI, Tokarev MM, Cacciola G, Restuccia G. Selective water sorbents for multiple applications, 1. $\mathrm{CaCl} 2$ confined in mesopores of silica gel: Sorption properties. React Kinet Catal Lett 1996;59:325-33. https://doi.org/10.1007/BF02068130. 
[57] Courbon E, D’Ans P, Permyakova A, Skrylnyk O, Steunou N, Degrez M, et al. Further improvement of the synthesis of silica gel and $\mathrm{CaCl} 2$ composites: Enhancement of energy storage density and stability over cycles for solar heat storage coupled with space heating applications. Sol Energy 2017;157:532-41. https://doi.org/10.1016/j.solener.2017.08.034.

[58] Gaeini M, Rouws AL, Salari JWO, Zondag HA, Rindt CCM. Characterization of microencapsulated and impregnated porous host materials based on calcium chloride for thermochemical energy storage. Appl Energy 2018;212:1165-77. https://doi.org/10.1016/j.apenergy.2017.12.131.

[59] Gordeeva LG, Restuccia G, Cacciola G, Aristov YI. Selective water sorbents for multiple applications, 5. LiBr confined in mesopores of silica gel: Sorption properties. React Kinet Catal Lett 1998;63:81-8. https://doi.org/10.1007/BF02475434.

[60] Gordeeva LG, Aristov YI. Composite sorbent of methanol "LiCl in mesoporous silica gel” for adsorption cooling: Dynamic optimization. Energy 2011;36:1273-9. https://doi.org/10.1016/j.energy.2010.11.016.

[61] Brancato V, Gordeeva LG, Grekova AD, Sapienza A, Vasta S, Frazzica A, et al. Water adsorption equilibrium and dynamics of LICL/MWCNT/PVA composite for adsorptive heat storage. Sol Energy Mater Sol Cells 2019;193:133-40.

https://doi.org/10.1016/j.solmat.2019.01.001.

[62] Hongois S, Kuznik F, Stevens P, Roux J-J. Development and characterisation of a new MgSO4-zeolite composite for long-term thermal energy storage. Sol Energy Mater Sol Cells 2011;95:1831-7. https://doi.org/10.1016/j.solmat.2011.01.050.

[63] Narayanan S, Li X, Yang S, McKay I, Kim H, Wang EN. Design and Optimization of High Performance Adsorption-Based Thermal Battery. Vol. 1 Heat Transf. Energy Syst. Thermophys. Prop. Theory Fundam. Res. Heat Transf., American Society of 
Mechanical Engineers; 2013. https://doi.org/10.1115/HT2013-17472.

[64] Mehrabadi A, Farid M. New salt hydrate composite for low-grade thermal energy storage. Energy 2018;164:194-203. https://doi.org/10.1016/j.energy.2018.08.192.

[65] Bouché M, Richter M, Linder M. Heat transformation based on $\mathrm{CaCl} 2 / \mathrm{H} 2 \mathrm{O}-\mathrm{Part} \mathrm{B}$ : Open operation principle. Appl Therm Eng 2016;102:641-7. https://doi.org/10.1016/j.applthermaleng.2016.03.102.

[66] de Jong A-J, Trausel F, Finck C, van Vliet L, Cuypers R. Thermochemical Heat Storage - System Design Issues. Energy Procedia 2014;48:309-19. https://doi.org/https://doi.org/10.1016/j.egypro.2014.02.036.

[67] Donkers PAJ, Pel L, Adan OCG. Experimental studies for the cyclability of salt hydrates for thermochemical heat storage. J Energy Storage 2016;5:25-32. https://doi.org/10.1016/j.est.2015.11.005.

[68] Whiting GT, Grondin D, Stosic D, Bennici S, Auroux A. Zeolite-MgCl2 composites as potential long-term heat storage materials: Influence of zeolite properties on heats of water sorption. Sol Energy Mater Sol Cells 2014;128:289-95. https://doi.org/10.1016/j.solmat.2014.05.016.

[69] Jabbari-Hichri A, Bennici S, Auroux A. CaCl2-containing composites as thermochemical heat storage materials. Sol Energy Mater Sol Cells 2017;172:177-85. https://doi.org/10.1016/j.solmat.2017.07.037.

[70] Frazzica A, Cabeza LF. Recent Advancements in Materials and Systems for Thermal Energy Storage. Cham: Springer International Publishing; 2019. https://doi.org/10.1007/978-3-319-96640-3.

[71] Hermosilla-Lara G. Stockage de l'hydrogène par adsorption sur charbon actif : Etude des effets thermiques lors de la charge dynamique d'un réservoir à lit fixe adsorbant. Université Joseph-Fourier - Grenoble I, 2007. 
[72] Oskouei MK, Tamainot-Telto Z. Effect of packing density on thermal properties of granular activated carbon packed bed by using of inverse heat conduction method. 10th Int. Conf. Heat Transf. Fluid Mech. Thermodyn., 2014, p. 944-8.

[73] JIN Z, TIAN B, WANG L, WANG R. Comparison on Thermal Conductivity and Permeability of Granular and Consolidated Activated Carbon for Refrigeration. Chinese J Chem Eng 2013;21:676-82. https://doi.org/10.1016/S1004-9541(13)60525$\mathrm{X}$.

[74] Verma R, Nagendra HN, Kasthurirengan S, Shivaprakash NC, Behera U. Thermal conductivity studies on activated carbon based cryopanel. IOP Conf Ser Mater Sci Eng 2019;502:012197. https://doi.org/10.1088/1757-899X/502/1/012197.

[75] Menard D, Py X, Mazet N. Activated carbon monolith of high thermal conductivity for adsorption processes improvement. Chem Eng Process Process Intensif 2005;44:1029_ 38. https://doi.org/10.1016/j.cep.2005.02.002.

[76] Kuwagaki H, Meguro T, Tatami J, Komeya K, Tamura K. An improvement of thermal conduction of activated carbon by adding graphite. J Mater Sci 2003;38:3279-84. https://doi.org/10.1023/A:1025138005230.

[77] Casey SP, Elvins J, Riffat S, Robinson A. Salt impregnated desiccant matrices for 'open' thermochemical energy storage-Selection, synthesis and characterisation of candidate materials. Energy Build 2014;84:412-25. https://doi.org/10.1016/j.enbuild.2014.08.028.

[78] Rehman AU, Khan M, Maosheng Z. Hydration behavior of MgSO4-ZnSO4 composites for long-term thermochemical heat storage application. J Energy Storage 2019;26:101026. https://doi.org/10.1016/j.est.2019.101026.

[79] Wang Q, Xie Y, Ding B, Yu G, Ye F, Xu C. Structure and hydration state characterizations of MgSO4-zeolite 13x composite materials for long-term 
thermochemical heat storage. Sol Energy Mater Sol Cells 2019;200:110047. https://doi.org/10.1016/j.solmat.2019.110047.

[80] Donkers PAJ, Sögütoglu LC, Huinink HP, Fischer HR, Adan OCG. A review of salt hydrates for seasonal heat storage in domestic applications. Appl Energy 2017;199:4568. https://doi.org/10.1016/j.apenergy.2017.04.080.

[81] Ferchaud C;, Zondag HA;, Boer R De. Material research on salt hydrates for seasonal heat storage application in a residential environment. Proc Int Symp Innov Mater Process Energy Syst 2013:4-6.

[82] Linnow K, Niermann M, Bonatz D, Posern K, Steiger M. Experimental Studies of the Mechanism and Kinetics of Hydration Reactions. Energy Procedia 2014;48:394-404. https://doi.org/10.1016/j.egypro.2014.02.046.

[83] Grevel K-D, Majzlan J, Benisek A, Dachs E, Steiger M, Fortes AD, et al. Experimentally Determined Standard Thermodynamic Properties of Synthetic MgSO 4 .4H 2 O (Starkeyite) and MgSO 4 ·3H 2 O: A Revised Internally Consistent Thermodynamic Data Set for Magnesium Sulfate Hydrates. Astrobiology 2012;12:1042-54. https://doi.org/10.1089/ast.2012.0823.

[84] Fopah Lele A, Kuznik F, Opel O, Ruck WKL. Performance analysis of a thermochemical based heat storage as an addition to cogeneration systems. Energy Convers Manag 2015;106:1327-44. https://doi.org/10.1016/j.enconman.2015.10.068.

[85] Ferchaud CJ, Zondag HA, Rubino A, De Boer R. Seasonal sorption heat storage Research on thermochemical materials and storage performance. Proc. Heat Power Cycle 2012, 2012, p. 1-7.

[86] Bertsch F, Jaehnig D, Asenbeck S, Kerskes H, Drueck H, Wagner W, et al. Comparison of the Thermal Performance of a Solar Heating System with Open and Closed Solid Sorption Storage. Energy Procedia 2014;48:280-9. 
https://doi.org/10.1016/j.egypro.2014.02.033.

[87] Boer R de, Haije WG, Veldhuis JBJ, Smeding Petten (Netherlands)] SF [ECN EE in IEEI. Solid-sorption cooling with integrated thermal storage. The SWEAT prototype. Netherlands: 2004.

[88] Sher F, Iqbal SZ, Albazzaz S, Ali U, Mortari DA, Rashid T. Development of biomass derived highly porous fast adsorbents for post-combustion $\mathrm{CO} 2$ capture. Fuel 2020;282:118506. https://doi.org/10.1016/j.fuel.2020.118506.

[89] Jubeen F, Liaqat A, Sultan M, Zafar Iqbal S, Sajid I, Sher F. Green synthesis and biological evaluation of novel 5-fluorouracil derivatives as potent anticancer agents. Saudi Pharm J 2019;27:1164-73. https://doi.org/10.1016/j.jsps.2019.09.013.

[90] Jubeen F, Liaqat A, Amjad F, Sultan M, Iqbal SZ, Sajid I, et al. Synthesis of 5Fluorouracil Cocrystals with Novel Organic Acids as Coformers and Anticancer Evaluation against HCT-116 Colorectal Cell Lines. Cryst Growth Des 2020;20:240614. https://doi.org/10.1021/acs.cgd.9b01570.

[91] Kuznik F, Johannes K, Obrecht C, David D. A review on recent developments in physisorption thermal energy storage for building applications. Renew Sustain Energy Rev 2018;94:576-86. https://doi.org/10.1016/j.rser.2018.06.038.

[92] Yao Z, You S, Ge T, Wang C-H. Biomass gasification for syngas and biochar coproduction: Energy application and economic evaluation. Appl Energy 2018;209:4355. https://doi.org/10.1016/j.apenergy.2017.10.077.

[93] Grevel K-D, Majzlan J. Internally consistent thermodynamic data for magnesium sulfate hydrates. Geochim Cosmochim Acta 2009;73:6805-15. https://doi.org/10.1016/j.gca.2009.08.005.

[94] Kleiner F, Posern K, Osburg A. Thermal conductivity of selected salt hydrates for thermochemical solar heat storage applications measured by the light flash method. 
Appl Therm Eng 2017;113:1189-93.

https://doi.org/10.1016/j.applthermaleng.2016.11.125.

[95] Thommes M, Kaneko K, Neimark A V., Olivier JP, Rodriguez-Reinoso F, Rouquerol J, et al. Physisorption of gases, with special reference to the evaluation of surface area and pore size distribution (IUPAC Technical Report). Pure Appl Chem 2015;87:105169. https://doi.org/10.1515/pac-2014-1117.

[96] Zuo S, Yang J, Liu J, Cai X. Significance of the carbonization of volatile pyrolytic products on the properties of activated carbons from phosphoric acid activation of lignocellulosic material. Fuel Process Technol 2009;90:994-1001. https://doi.org/10.1016/j.fuproc.2009.04.003.

[97] R. Byron Bird, Stewart WE, Lightfoot EN. Transport Phenomena, Revised 2nd Edition. 2007.

[98] Wang Y, Kuckelkorn J, Zhao F-Y, Spliethoff H, Lang W. A state of art of review on interactions between energy performance and indoor environment quality in Passive House buildings. Renew Sustain Energy Rev 2017;72:1303-19. https://doi.org/10.1016/j.rser.2016.10.039.

[99] ThemExcel. Production of domestic hot water 2021. https://www.thermexcel.com/french/ressourc/dimensionnement_production_eau_chaud e_sanitaire.htm. 